\title{
PATRIMÔNIO, TRABALHO E TEMPO: O "NOVO" MERCADO MUNICIPAL DO RIO DE JANEIRO
}

\author{
Nina Pinheiro Bitar ${ }^{1}$
}

Os mercados de abastecimento de cidades são espaços onde são realizadas mediações entre diferentes espaços, pessoas e objetos. Eles concentram por excelência momentos de trocas comerciais e proporcionam, para além de transações econômicas, relações sociais e simbólicas.

Vistos outrora como locais "sujos" ou que "atrapalhavam" o desenvolvimento das cidades - motivo pelo qual muitos mercados foram remanejados para a periferia das cidades - passam agora a ser percebidos como espaços de expressão de autenticidade e estilos de relações sociais não contaminadas pela impessoalidade do ambiente "moderno". Esses espaços passam a ser um local "visitado" e onde se pode "viver uma experiência", muitos deles sendo objeto de processos de "patrimonialização" por agências de preservação histórica.

O Centro de Abastecimento do Estado da Guanabara (Cadeg), no Rio de Janeiro, tornou-se um lugar de pesquisa, onde abordei (Bitar, 2014) o seu cotidiano a partir do ponto de vista de seus comerciantes, funcionários, produtores e fregueses. ${ }^{2}$ Observei que esse mercado passava por transformações em seus usos, por uma reconfiguração do seu espaço e dos seus significados para essa cidade.

A ligação entre as categorias "mercado" e "cidade" é comum nos estudos sobre o tema. Weber (1979) é uma importante referência ao formular que a existência das trocas mercantis permanentes é um fator fundamental para a constituição das chamadas "cidades". Ele conceitua que a formação das cidades baseia-se em dois fundamentos: "a existência de uma sede senhorial-territorial" e a existência de um "mercado", o local onde se realizam as trocas de bens de forma regular para a satisfação das necessidades dos moradores.

Somente queremos falar de "cidade" no sentido econômico, tratando-se de um lugar onde a população local satisfaz no mercado local uma parte economicamente essencial de suas necessidades cotidianas, e isto principalmente com produtos que a população local e dos arredores produziu ou adquiriu para a

\footnotetext{
${ }^{1}$ Universidade Federal do Rio de Janeiro, Brasil.

${ }^{2} \mathrm{O}$ presente trabalho foi realizado com apoio do CNPq, Conselho Nacional de Desenvolvimento Científico e Tecnológico - Brasil
} 
venda no mercado. Toda cidade no sentido aqui adotado da palavra é "localidade de mercado", isto é, tem um mercado local como centro econômico do povoado, mercado no qual, em virtude da existente especialização da produção econômica, também a população não urbana satisfaz suas necessidades de produtos industriais ou artigos mercantis ou de ambos e, como é natural, também os próprios moradores da cidade trocam entre si os produtos especiais e satisfazem as necessidades de consumo de suas economias. Originalmente, era normal que a cidade, onde se apresentava como complexo distinto do campo, fosse ao mesmo tempo sede de um senhor territorial ou príncipe e localidade de mercado, possuindo centros econômicos de ambos os tipos - oikos e mercado - e frequentemente nela ocorressem, periodicamente, ao lado do mercado local, feiras de comerciantes viajantes, vindos de longe. Mas a cidade (no sentido aqui adotado da palavra) é um assentamento com mercado permanente (1979, p. 409-410).

O autor define, assim, ser o mercado um elemento fundador das cidades, com função primordial tanto para o abastecimento quanto para a "povoação das mesmas". A ligação entre as categorias "mercado" e espaços citadinos é recorrente na bibliografia sobre o tema mercados. Pode-se perceber que a característica espacial é elementar segundo os títulos das obras: La Economía de un Sistema de Mercados en México - Un ensayo de Etnografía Contemporánea y Cambio Social en un Valle Mexicano (Malinowski \& La Fuente, 1957), "Suq: the bazaar economy in Sefrou" (Geertz, 1979), Market Day in Provance (La Pradelle, 2006), A feira do anjo da guarda: estudos de uma Instituição Econômica num município Sergipano de São Francisco (Mott, 1975), Feira e trabalhadores rurais: As feiras do Brejo e do Agreste Paraibano (Garcia, 1984), entre outros igualmente importantes. Destaco, desta forma, a centralidade da localização geográfica dos mercados para a composição das descrições e das análises sobre mercados, concepção esta também compartilhada em minha pesquisa.

Busco, entretanto, fazer um caminho inverso: partir do próprio espaço do mercado para abordar como uma cidade é constituída. A partir das narrativas dos comerciantes do mercado é formada uma concepção de cidade - no caso, o Rio de Janeiro - e suas transformações ao longo do tempo. Questiono quais são as concepções de projetos de cidade que envolvem esses mercados e como são reformuladas pelas pessoas que lá "habitam" (Ingold, 2000, Heidegger, 1992). ${ }^{3}$

Nesta perspectiva, o mercado é formador da cidade, ao mesmo tempo em que é por ela constituído. Como podemos narrar os imaginários de cidades a partir de um

\footnotetext{
${ }^{3}$ Os mercados, assim como as cidades, podem ser vistos a partir da perspectiva do "habitar", já que "construímos porque habitamos", segundo o autor.
} 
mercado? Qual cidade é construída nesse contexto? A cidade do Rio de Janeiro emerge das narrativas das pessoas envolvidas no mercado, ela não existe como um dado a priori. O panorama da pesquisa é uma reflexão sobre os usos e as representações do espaço urbano da cidade do Rio de Janeiro em comparação com outros locais através de narrativas sobre processos de apropriação do espaço público, buscando investigar os modos pelos quais se produzem os "imaginários" das cidades (Durand, 1993, 2002; Eckert \& Rocha, 2000b, 2013a, 2013b, 2013c).

Pretendo contribuir para esse debate trazendo nesse artigo o espaço do mercado através das redes de reciprocidade estabelecidas (Mauss, 2003). Ele é um agente que constitui, no caso, a cidade do Rio de Janeiro, e não apenas um reflexo de processos de formação de povoados ou cidades. Assim, as categorias "cidade" e "mercado" emergirão etnograficamente, não as tomarei como já estabelecidas.

Como muitos autores apontam, os mercados que comercializam diversos produtos e estão situados em variados contextos são espaços de trocas não apenas econômicas (Malinowski, 1957; Mintz, 1961, 1987, 1971, 2008; Mott, 1975, 1976; Silva, 1971; Garcia, 1977, 1983, 1984, 1993, 2010; Geertz, 1979; Sigaud, 1983; Gell, 1982; Clark, 1994; Carrier, 1997; Ferreti, 1985, 2000; Filgueiras, 2000; Stoller, 2002; Bestor, 2003, 2004; Gorberg \& Fridman, 2003; Rabossi, 2004; La Pradelle, 2006; Vedana, 2008; Zukin, 2008; Leitão, 2010; Durando, 2010; entre outros).

Compartilho desta perspectiva ao pensar o mercado como parte de relações de reciprocidade (Mauss, 2003). Para Mauss, as trocas envolvem características que ultrapassam as econômicas. Pode-se dizer que os mercados são instituições que manifestam o que Mauss (2003) denomina de "fato social total", um fenômeno que exprime as esferas religiosas, jurídicas, morais, econômicas, estéticas, morfológicas, e outras.

Percebi ao longo da pesquisa que as relações de reciprocidade são fundamentais. Através do sistema de prestações totais formulado por Mauss notei que as trocas que são realizadas no mercado envolvem diversas esferas da vida das pessoas que lá atuam. O mercado, nesse contexto estudado, aparece como um fator fundamental de constituição das pessoas, e é através dele que as pessoas narram a sua vida e imaginam uma cidade. Nessa perspectiva, o mercado é parte constituinte e constituidora da cidade. Desta forma, apresento uma pesquisa do Rio de Janeiro e não apenas no Rio de Janeiro Eckert \& Rocha (2013c). 


\section{O "novo" Mercado Municipal do Rio de Janeiro}

O mercado de abastecimento Cadeg é localizado na Rua Capitão Félix, 110, Benfica $^{4}$ e possui uma área construída de cerca de $100.000 \mathrm{~m}^{2}$. É situado próximo ao edifício Pedregulho ${ }^{5}$ e possui características arquitetônicas de sua fachada que fazem referência ao "modernismo" desse edifício.

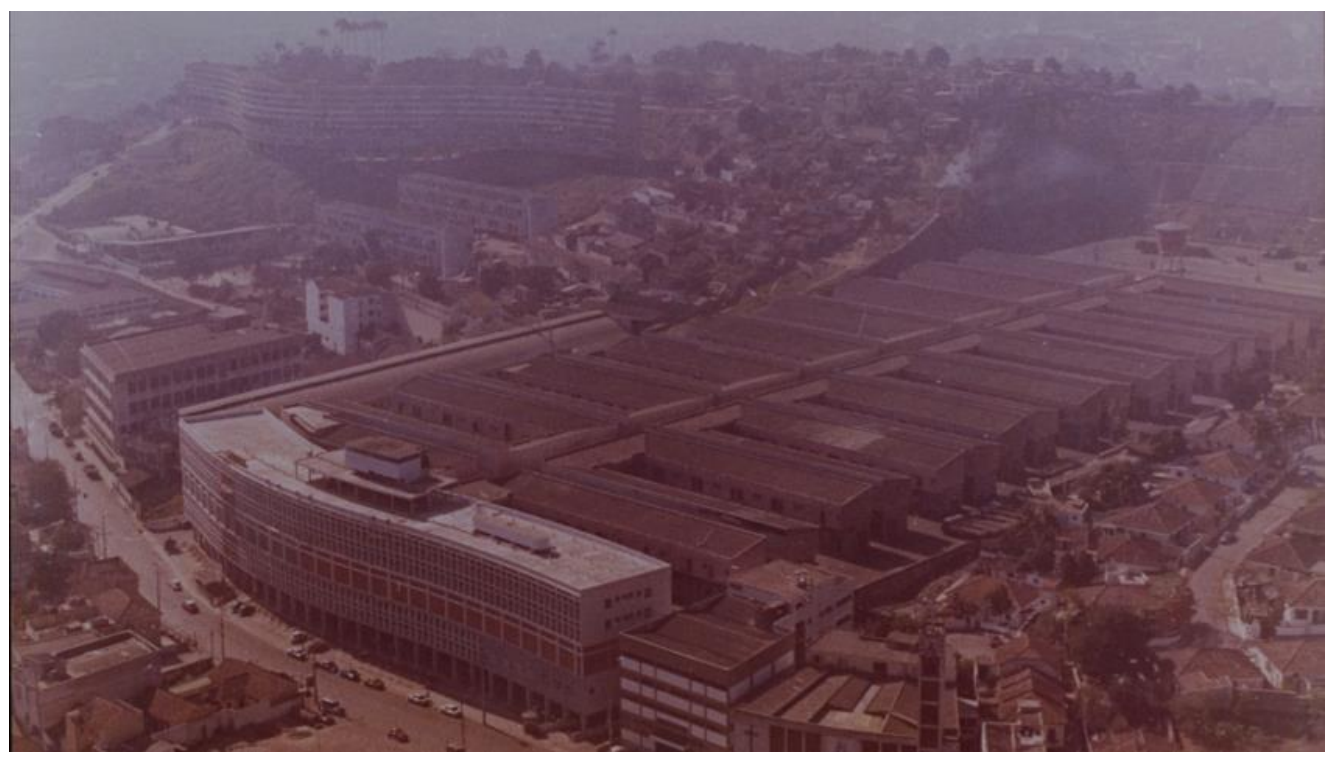

Cadeg em primeiro plano e ao fundo o Conjunto do Pedregulho (Acervo Cadeg, s/d)

O Cadeg é um mercado privado, foi fundado por imigrantes portugueses, italianos e seus descendentes, em sua maioria, no ano de 1962. Ele foi construído no terreno da antiga fábrica de cigarros Veado (Imperial Estabelecimento de Fumo, a primeira fábrica de cigarros do Brasil). Atualmente é o maior distribuidor de flores do Estado do Rio de Janeiro.

\footnotetext{
${ }^{4}$ Benfica é um bairro próximo a São Cristóvão, zona norte do Rio de Janeiro.

5 "Projetado pelo arquiteto modernista Affonso Eduardo Reidy, em 1947, o Conjunto Residencial Prefeito Mendes de Moraes, conhecido como "Conjunto do Pedregulho", foi construído para abrigar funcionários públicos do então Distrito Federal. Este edifício compõe a face social da arquitetura de Reidy; a estética e os princípios defendidos por Le Corbusier se fazem sentir no projeto, no cuidado com as tecnologias aplicadas na construção, na economia de meios utilizados e nas preocupações funcionais estreitamente relacionadas às soluções formais: controle da luz e da ventilação e facilidade de circulação”. Disponível em: http://www.capacete.net/files/roteiro.pdf. (Acesso: novembro, 2013)
} 


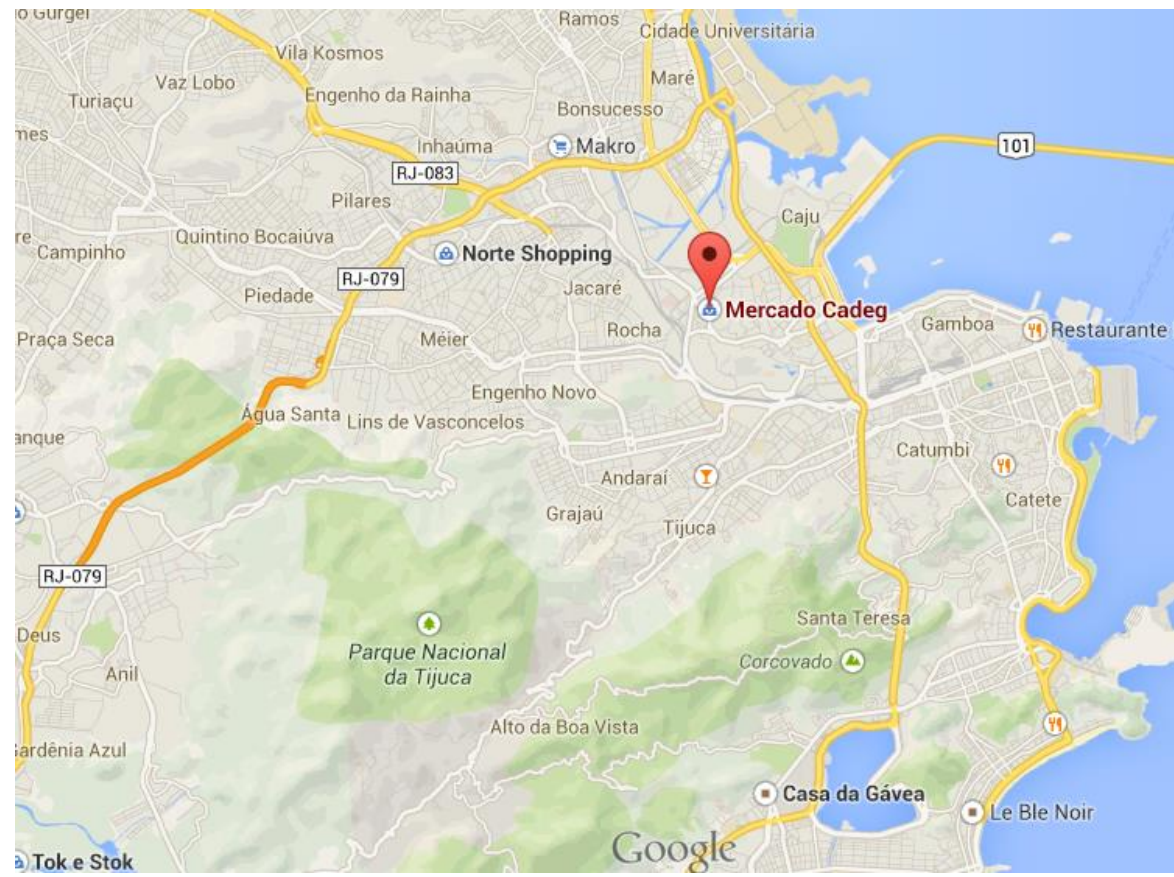

Mapa do entorno do Cadeg (Fonte: Google)

Através do contato que estabeleci com as pessoas que "fundaram" o mercado, classificados por eles como "fundadores", percebi que a sua relação está atrelada a um outro mercado, o Mercado Municipal da Praça XV de Novembro (1907-1962), que era localizado no centro da cidade, onde eles trabalharam e que foi extinto em 1962. Assim, as narrativas produzidas por eles estão vinculadas a outro "tempo".

Pode-se dizer que a extinção do Mercado Municipal da Praça XV de Novembro foi decorrência da implantação de novos planos urbanísticos na região do centro da cidade do Rio de Janeiro na década de 60, como a finalização da construção da Avenida Perimetral, que "atravessou o mercado" exigindo a sua remoção do local. Além disso, o prazo de 50 anos de concessão pela Prefeitura do terreno do Mercado Municipal expirou em 1957, obrigando os comerciantes a saírem mais adiante do local. 


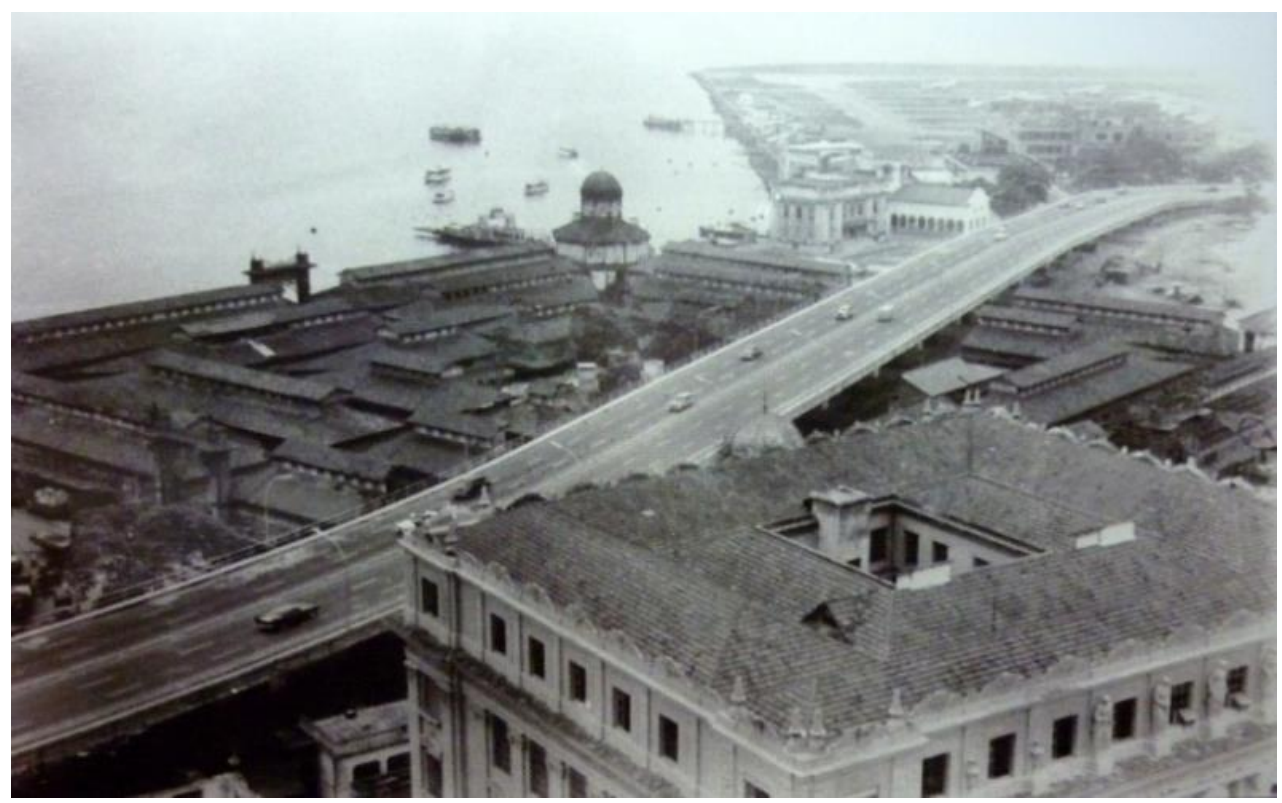

“Outro ângulo da Avenida Perimetral acima do Mercado Municipal” (Fonte: Gorberg \& Fridman, 2003)

Com a demolição do Mercado Municipal, ${ }^{6}$ os comerciantes uniram-se para construir um novo mercado em uma zona mais afastada do centro comercial da cidade, o Cadeg.

O processo de remoção de alguns mercados para zonas mais afastadas da área dos centros urbanos tem sido um caso comum em diversos países. É o caso do Cadeg, criado a partir da já comentada demolição do antigo Mercado Municipal do centro, que foi construído no bairro de Benfica, afastado do centro. ${ }^{7}$ Ocorreu processo semelhante em outros países, como, por exemplo, o mercado situado em Les Halles, no centro de Paris, que foi demolido em 1969 e transferido para Rugis, na periferia da cidade. Hoje essa área central reúne uma estação de metrô, restaurantes e bares (Vedana, 2008). Pode-se dizer que essas transformações fazem parte de um processo mais amplo de reconfiguração ou "gentrificação" ou "enobrecimento"8 (Zukin, 1989,

\footnotetext{
${ }^{6}$ Deste antigo mercado apenas restou um dos seus torreões, que não foi demolido, onde funciona o restaurante Albamar, sendo posteriormente tombado na década de 80 e transformado em "resquício" do Mercado Municipal e do "Rio antigo".

${ }^{7}$ A criação da Ceasa (Centrais de Abastecimento construídas na década de 70 pela ditadura militar), localizada em Irajá, zona norte do Rio de Janeiro, também faz parte desse processo.

${ }^{8}$ É atribuída a Ruth Grass (1964) a formulação do conceito gentrification, ao apontar as mudanças sociais e econômicas no mercado imobiliário de bairros operários londrinos. Leite aponta que o conceito gentrification pode ser traduzido como "enobrecimento", mas explica que "a tradução desse neologismo, derivado do inglês gentry, é ainda controversa nos estudos sobre o tema Brasil" (Leite, 2004, p. 33 apud Gaspar, 2012, p.14). Segundo Leite, o conceito de gentrification abrange: "[...] aquelas intervenções urbanas voltadas ao city marketing ou à transformação de degradados sítios históricos em áreas de entretenimento urbano e consumo cultural. Objetivando modernizar recursos
} 
2000b, 2008; Smith, 2004; Leite, 2004; Bidou-Zachariansen, 2006) de bairros localizados na zona central de cidades. ${ }^{9}$

Em 2012, um ato público conduzido pelo prefeito da cidade no evento de comemoração dos 50 anos do Cadeg, reconheceu o Cadeg como o novo Mercado Municipal do Rio de Janeiro. Tal nomeação refletiu o processo de ressignificação pelo qual o mercado vem passando nos últimos anos, tornando-se gradativamente um local de "entretenimento" de uma parcela da população.

Apesar de tal reconhecimento, o Cadeg já havia deixado de ocupar o lugar de abastecedor de alimentos da cidade. Em prosseguimento com as políticas de abastecimento e projetos urbanísticos aplicadas aos mercados, situando-os em locais mais afastados dos centros urbanos, foi criada a Ceasa (Centrais de Abastecimento construídas na década de 70 pela ditadura militar), localizada em Irajá, zona norte do Rio de Janeiro. ${ }^{10}$ Segundo os comerciantes do mercado, foi nesse momento que o Cadeg sofreu uma mudança abrupta em sua "biografia", passando a ter um papel secundário no abastecimento da cidade.

\section{Estrutura e funcionamento do mercado}

O Cadeg é uma construção classificada por arquitetos como característica da década de 60, com traços modernistas e que exibe uma fachada, orientada para o Noroeste, de elemento vazado de concreto que remete ao cobogó, ${ }^{11}$ além de brisesolei, ${ }^{12}$ que permitem a ventilação e o sombreamento de sua grande estrutura.

potenciais para melhor inserção na "concorrência intercidades" (Fortuna, 1997), através do uso estratégico do patrimônio, a mais recorrente característica dessas intervenções urbanas tem sido uma (re)localização estética do passado, cujo padrão alterado de práticas que mimetizam o espaço público torna o patrimônio uma mercadoria cultural, passível de ser reapropriada pela população e pelo capital" (Leite, 2006: 24 apud Gaspar, 2010: 2).

${ }^{9}$ Muitos mercados permaneceram nos centros urbanos, mas foram reincorporados ou ressignificados a partir desses processos mais amplos de "patrimonialização" (Fonseca, 2005; Gonçalves, 2003, 2007, 2008; Leitão, 2010). Alguns desses mercados foram alvo de tombamentos e registros por órgãos municipais, estaduais e federais de preservação patrimonial. ${ }^{9} \mathrm{O}$ Iphan, por exemplo, tombou diversos mercados desde a década de 50, como o Mercado da Diamantina (MG), o Mercado Modelo (Salvador, BA), o Mercado de São José (Recife, PE), o Mercado do Ver-o-Peso (Belém, PA), ${ }^{9}$ o Mercado de Carne (Aquiraz, CE), o Mercado Público de Manaus (AM). Já a Feira de Caruaru (PE) é considerada "patrimônio imaterial" pelo Iphan.

${ }^{10}$ A Ceasa-RJ é uma empresa vinculada à Secretaria de Estado de desenvolvimento regional, abastecimento e pesca.

${ }^{11}$ Denomina-se assim a peça de construção vazada, que pode ser feita de cerâmica, cimento ou gesso, dentre outros materiais. É utilizada em paredes e fachadas para obstruir a incidência direta dos raios solares e permitir a ventilação e a entrada de luz natural. O seu nome é formado pelas iniciais dos 
O Cadeg foi projetado pelos arquitetos Vigor Artesi (falecido) e Moacyr Gomes da Costa, ${ }^{13}$ contratados pelos comerciantes do Mercado Municipal da Praça XV de Novembro, antes de ser extinto. Segundo Gomes da Costa, ${ }^{14}$ para a elaboração do projeto de construção do Cadeg, ele e Artensi fizeram a pesquisa com os "futuros condôminos para saber o pensamento de cada um - do ponto de vista funcional, não estético". Eles conheciam os comerciantes que trabalhavam no Mercado Municipal da Praça XV de Novembro ${ }^{15}$, e perguntavam para eles: “como é que o senhor gostaria que fosse a sua loja?". A partir disso fizeram uma média e partiram para a elaboração da ideia do que seria o novo mercado. Assim, eles conversaram com comerciantes, funcionários, frequentadores e até com vendedores ambulantes do Mercado Municipal, "como uma espécie de pesquisa de opinião, para sentir o censo crítico de cada um sobre como entendiam um mercado".

Segundo o arquiteto, o "partido arquitetônico" 16 adotado para o projeto do Cadeg tinha influência do modernismo, principalmente de Lúcio Costa, Affonso Eduardo Reidy, Oscar Niemayer e Artigas, seguindo as suas "linhas básicas".

sobrenomes dos engenheiros que iniciaram o uso deste tipo de elemento vazado, em PE, nos anos 1930: Coimbra, Boeckmann e Góis. (Fonte: Portal Dicionário Aulete).

12 Também é utilizado para impedir a incidência direta de radiação solar e muito utilizado pela "arquitetura moderna".

${ }^{13} \mathrm{O}$ arquiteto Vigor Artesi participou do Concurso para o Plano Piloto da Nova Capital Federal (Brasília), com o plano de número 23, juntamente com Marcelo Rangel Pestana, engenheiro, e Hérnan Ocampo Landa, arquiteto

(Fonte: http://www.guiadebrasilia.com.br/historico/memoria_city/concurso_plano.html). O arquiteto Moacyr Gomes da Costa construiu o estádio João Cláudio de Vasconcelos Machado, em Natal, demolido para a construção da Arena das Dunas, para a Copa de 2014. Para mais informações sobre Moacyr, ver: http://www. vitruvius.com.br/revistas/read/entrevista/14.054/4757 ou http://manucarpediem.wordpress.com/2009/04/28/ moacyr-gomes-sua-obra-e-o-machadao/. (Acesso em: novembro 2013).

${ }^{14}$ Conversei com ele por telefone e e-mail em novembro de 2013, o arquiteto morava em Natal no período. Agradeço ao arquiteto pela disponibilidade. Ver mais informações sobre a construção em Bitar (2014).

${ }^{15}$ Parte dos comerciantes do Mercado Municipal da Praça XV de Novembro, localizado no centro do Rio de Janeiro, uniram-se para construir o Cadeg, com a extinção desse antigo mercado em 1962.

16 “O Partido Arquitetônico é um conjunto de diretrizes e parâmetros que são levados em conta na realização de um projeto arquitetônico e/ou urbanístico". Dentre os parâmetros, são considerados, por exemplo: o tipo de terreno, a finalidade da construção, a implantação dependendo da geografia do terreno, os conceitos que definem o estilo, a legislação, a viabilidade do projeto, entre outros (Fonte: arquiteturaeeducacao.blogspot.com.br/ 2013/07/partido-arquitetonico.html. Acesso em: junho 2014). 


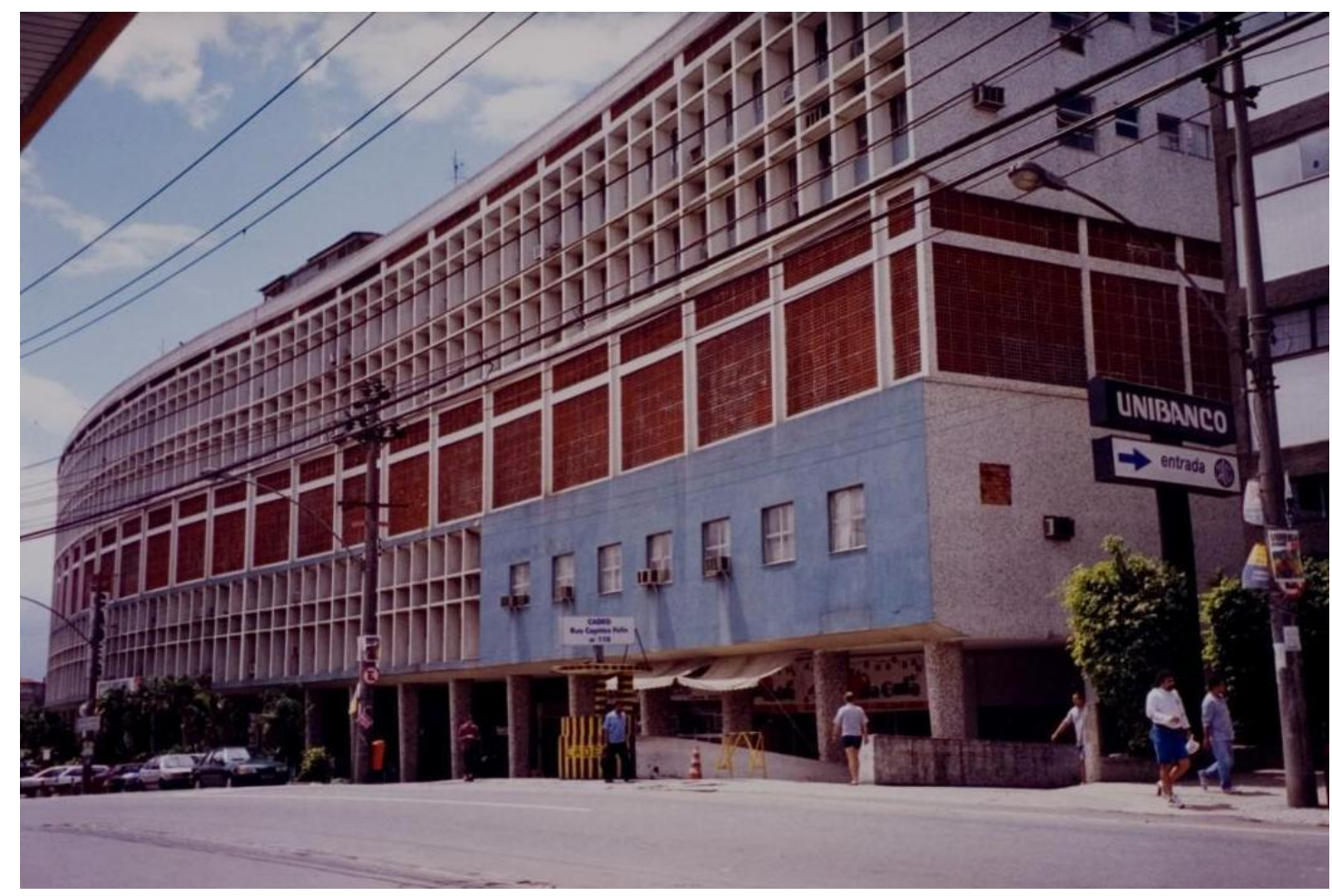

Fachada Cadeg (Acervo Cadeg, s/d)

Ao avistarmos a construção do mercado, podemos ver seu prédio de fachada modernista e as grades que cercam a portaria, local onde os homens que fazem a "segurança" da entrada do térreo do mercado. Logo na entrada estão localizadas as "escadas rolantes" que cortam a Galeria Central do térreo. No lado esquerdo da galeria há lanchonetes, botequins, loja de sapato, casa lotérica, correios; no lado direito localizam-se dois elevadores, uma loja de recarga de celulares, uma loja de artigos para festas, papelaria, loja de informática, cabeleireiro. No final da Galeria Central, encontra-se o estacionamento do térreo. Nas seis galerias perpendiculares distribuem-se lojas de camisas, de artigos para festa, chaveiros, barbearia, entre outros. Tal espaço parecia ser predominantemente masculino, impressão talvez formada pela presença constante de homens no botequim da entrada.

A escada rolante leva ao primeiro andar do mercado. É onde se situam a entrada para as salas da Diretoria, a Secretaria do Cadeg e o auditório de eventos. Nesse andar, encontram-se lojas de cosméticos, de bebidas (especializada em vinhos), um caixa-eletrônico 24 horas, loja de sucos e estacionamento ao fundo.

Subindo novamente a escada rolante, chega-se ao andar principal, o segundo andar, onde se concentra o maior número de lojas do mercado. A Avenida Central é 
cortada por 17 ruas perpendiculares, e as lojas, ao longo do seu enorme corredor, são revestidas de cobogó, assim como a fachada do prédio. Este andar tem uma cobertura de ventilação e iluminação zenitais. Na avenida e ruas há lojas bem diversificadas, as quais vendem tanto por atacado quanto no varejo. Nas lojas de venda por atacado existem, por exemplo, lojas que vendem uma só categoria de produto: loja somente de banana, de abacaxi, de abóboras etc. Há também as que vendem hortifrutigranjeiros variados. As lojas que comercializam no varejo oferecem desde bebidas - em lojas especializadas, que fazem degustação - até flores.

Os "carregadores" estacionam os seus "carrinhos", também chamados de "burros sem rabo", num local reservado para eles ao longo de toda a avenida. Por ela e suas ruas transversais localizam-se os restaurantes, os quais passaram por um processo de expansão, fazendo do Cadeg o novo "polo gastronômico" do Rio de Janeiro. Destaca-se ainda o "Cantinho das Concertinas", nome dado ao espaço dedicado às "tradições" gastronômicas e musicais portuguesas.

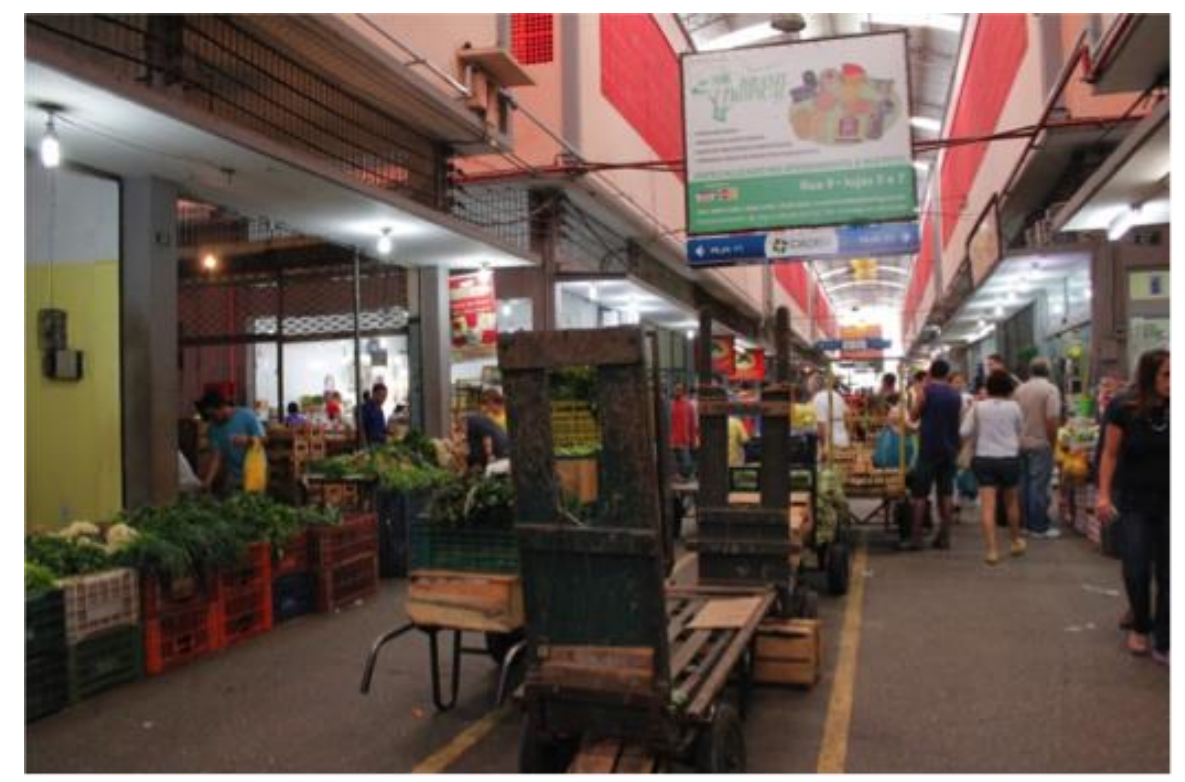

"Burros sem rabo" estacionados na Avenida Central. Rio de Janeiro, manhã de 19 de novembro de 2011 (Fotografia: Nina Pinheiro Bitar)

Ao percorrer as ruas até o final da Avenida Central, percebe-se uma mudança nos padrões das lojas. Quanto mais próximo da Praça Geral, ao fundo do mercado, maior o número de lojas que vendem flores ou artigos para decoração de arranjos florais. Na área da Praça Geral, está localizado o Galpão das Flores. É o local também de estacionamento de veículos particulares e de carga e descarga de caminhões. As 
caixas que entram e saem do mercado são organizadas em pilhas, próximo à saída do estacionamento.

Nos $3^{\circ}$ e $4^{\circ}$ andares, com acesso apenas pela escada de emergência e elevadores, localizam-se principalmente escritórios variados. Por se tratar do prédio de fachada, longos corredores acompanham a curva da rua em frente ao mercado. As salas comerciais são posicionadas ao longo do corredor, dos seus dois lados, e têm aproximadamente 20 metros quadrados, divididos em sala, dois quartos, banheiro e cozinha. A vista é panorâmica, podendo-se ver algumas favelas que cercam o mercado, como Mangueira, Barreira do Vasco, entre outras. O $5^{\circ}$ andar está desativado, e é chamado por eles de terraço.

A maioria das lojas de hortifrutigranjeiros funciona de 2 horas da madrugada às 12 horas, mas o mercado ainda continua aberto até as 17 horas, com apenas alguns restaurantes e lojas de bebidas funcionando nos dias de semana. Já nos finais de semana as lojas de hortifrutigranjeiros começavam a funcionar em horários diferenciados dos demais dias de semana, fechando mais tarde.

Classificadas pelos comerciantes, as "manhãs", quando começa o comércio, correspondiam ao período entre 2 às 9 horas; o "final das manhãs" ia das 9 às 12 horas; e as "tardes" eram das 12 às 18 horas. As lojas de venda a atacado encerravam as suas atividades por volta do final da manhã, já os restaurantes e lojas de venda a varejo permaneciam abertas até as 16 horas nos dias de semana e até 18 horas nos finais de semana. Essa divisão, que era formulada pelos comerciantes do mercado, expressava também as camadas de tempo que eles concebiam, demonstrando uma segmentação da percepção da categoria "tempo".

Tal classificação dos "horários" também expressava uma hierarquia temporal, dependendo de cada tipo de comércio. Para os vendedores de hortifrutigranjeiros por atacado, o horário de 2 às 7 da manhã era o melhor período de venda, quando sua mercadoria "saía" num maior montante. Era também um período em que os comerciantes estavam mais bem dispostos, pois era o início da venda. No final de manhã estava mais vazio e eles, cansados, já começavam a se preparar para encerrar o expediente. Para esses comerciantes de hortifrutigranjeiros e cereais, entre outros, quase não existia comercialização nas tardes dos dias de semana. Em outros setores, como o de restaurantes, era o contrário. Quase nenhum deles funcionava de madrugada e os seus melhores horários de funcionamento eram o final da manhã e as 
tardes dos dias de semana e de sábado. Ainda havia os bares, chamados "pés sujos", que tinham movimento em quase todos os períodos e eram frequentados principalmente pelos comerciantes do mercado, além dos atravessadores que levavam as mercadorias lá.

Percebi que a categoria "tempo" era primordial para os comerciantes. Ela se expressava tanto através dos horários de comercialização quanto no fluxo semanal de trabalho. O fluxo de trabalho semanal pode ser agrupado, segundo a classificação dos trabalhadores, entre "dias de semana" e "sábado". ${ }^{17}$ Esta era uma distinção fundamental para eles, pois alterava-se o perfil do público e do tipo de venda conforme esses diferentes "tempos". Estes são dois marcos temporais que estruturam a vida dos comerciantes do Cadeg. ${ }^{18}$

Nos dias de semana, de acordo com eles, a venda era predominantemente no atacado, principalmente de hortifrutigranjeiros. Os comerciantes começavam a chegar ao Cadeg aproximadamente às 22 ou 23 horas, abriam as suas lojas e começavam a vender de 2 da manhã até as 10 horas. Alguns varejistas que comercializavam hortifrutigranjeiros, cereais, bebidas, entre outros, permaneciam com suas lojas abertas até o meio-dia. Os restaurantes começavam a ter um maior número de clientes - segundo eles, "maior movimento"19 - do meio-dia até as 16 horas. Cada comerciante encerrava a sua atividade conforme a "diminuição do movimento".

Eles reproduziam esse ciclo até sábado, que tinha um horário e um ritmo diferenciados. O número de pessoas que visitava o mercado, que eles chamavam de "fluxo de clientes", era maior no sábado do que nos dias de semana, o que era visivelmente percebido nos corredores das ruas do mercado.

No sábado, além da venda a atacado, realizada de madrugada, havia no período do final da manhã uma maior procura da clientela pelo comércio a varejo. Os comerciantes também apontavam que os fregueses então "mudavam de perfil", sendo um público mais voltado para a compra de poucos itens, em menor quantidade, e também que iam ao mercado para "passear", para o "lazer" e almoçar. Aos sábados

\footnotetext{
${ }^{17}$ Os restaurantes e poucos comerciantes abriram nos domingos no período da pesquisa.

${ }^{18}$ Garcia (1984) apontou em seu trabalho sobre as feiras do agreste paraibano a importância dessa divisão temporal nas vendas. No contexto estudado pela autora, os dias de semana eram direcionados à venda no atacado e os finais de semana à venda a varejo.

${ }^{19}$ Movimento, para eles, era uma clientela comprando constantemente. Quando o período de tempo entre um cliente e outro aumenta, quer dizer que está "acabando o movimento".
} 
acontecia a "festa portuguesa" no Cantinho das Concertinas, comandada pelo Carlinhos.

Segundo o site do Cadeg, ${ }^{20}$ a classificação geral das lojas era de: bebidas (vinhos, espumantes e cervejas nacionais e importadas); calçados e vestuários (confecção de uniformes profissionais, comércio de sapatos masculinos e femininos, bolsas, cintos); cereais e mercearia ("atacadista de gêneros alimentícios, produtos de limpeza e bebidas em geral", "bacalhau, azeites e vinhos", "atacado de cereais", “comércio de frutas, legumes e cereais"); descartáveis (como, por exemplo, embalagens de plástico); diversos (lojas de purificadores de água, ar-condicionado, suprimentos de informática, cereais, produtos de limpeza e bebidas); doces ("atacadista e varejista de balas e confeitos", confeitaria, "cereais, bebidas, produtos de limpeza, doces"); flores e decoração (“embalagens e acessórios de decoração para floricultura", "objetos para decoração", como vidros, flores artificiais e desidratadas, fibra de coco", cestas, descartáveis, artigos para decoração, miniaturas, sachê, blister, “artesanato de vidros"); gastronomia (cafeteria, bar, restaurante, "laticínios, frios, gastronomia e bebidas", restaurante self-service, sucos naturais); hortifruti (frutas e legumes, "hortifruti e granjeiros"); laticínios e frios (laticínios, gastronomia, bebidas, cereais, temperos); serviços (como bancos, táxis, loteria, seguros, centro médico, escritórios de contabilidade, correio etc.). Vale observar que as classificações das lojas se misturavam, pois muitas delas não se enquadravam em apenas uma especificação.

Os nomes das lojas também tinham peculiaridades, como: Casa do Alho, Casa Santo Antônio, Bananas Vip, Sapataria e Camisaria Feirante, Chico Flores, Carla Flores, Egg Show, Armazém do Queijo, Empório Quitanda, Dream Beer, Planet Drinks, entre muitas outras.

Entretanto, a maioria dos comerciantes não sabia o nome das lojas, apenas as chamavam pelo nome do seu dono ou vendedor. Cada vendedor estava fortemente vinculado à sua mercadoria, como: "Seu Antônio das abóboras", "Agostinho das batatas", "Seu Orlando das cestas", "Jin dos cereais", "Seu Germano das laranjas", "Marcelo do restaurante Barsa", "Chico das flores", e muitos outros.

As pessoas no mercado recebiam também uma classificação pelo produto que comercializam: existiam os "verdureiros"; os "cerealistas" (pessoas que vendiam

\footnotetext{
${ }^{20}$ Disponível em: http://www.cadeg.com.br
} 
cereais: arroz, feijão, farinha, grãos etc.); os "atacadistas" (vendiam a atacado banana, abacaxi, abóbora, cebola, batatas etc.); “varejistas” (comercializavam a varejo os mais diversos produtos, especialmente hortifruti e produtos industrializados); e ainda as pessoas que vendiam outros artigos, como produtos portugueses, bacalhau e azeite, e também laticínios, cestas, descartáveis e flores.

Os comerciantes ${ }^{21}$ que eram proprietários das lojas, chamados “donos da loja”, pagavam o condomínio, no valor aproximado de $\mathrm{R} \$ 700$, cota extra, luz e gás. Aqueles que não eram proprietários, pagavam aproximadamente $\mathrm{R} \$ 3$ mil de aluguel pela sua loja, dependendo de sua localização, e R\$ 700 de condomínio, além de cota extra para a manutenção do mercado, luz e gás. $\mathrm{O}$ valor do aluguel dependia do lugar em que a loja se situava, podendo chegar a $\mathrm{R} \$ 5$ mil em alguns pontos mais valorizados. A proximidade com a Avenida Central - por ser o local que agregava o maior número de pessoas no mercado, dando maior visibilidade ao seu negócio - era um dos fatores de valorização do imóvel. ${ }^{22}$ Alguns deles podiam ser vendidos até por $\mathrm{R} \$ 500$ mil. Os comerciantes afirmavam que houve uma valorização imobiliária no Cadeg em consequência da recente implantação de UPPs (Unidades de Polícia Pacificadora) nas favelas da redondeza, ${ }^{23}$ o que teria tornado o bairro de Benfica mais seguro. Como veremos à frente, outros fatores também contribuíram para as recentes transformações desse mercado.

\section{Cotidiano no mercado}

O comerciante Zé se autodenomina "verdureiro", atividade que desenvolvia havia pouco tempo, há cinco anos, mas ele trabalhava há mais de 40 anos no Cadeg, pois antes era "carregador" de lá. Ele divide o aluguel de uma loja localizada no início da Avenida Central, que também chama de box, com o seu irmão, que vende frutas. A bancada de madeira das mercadorias de Zé fica na porta da loja, onde estão dispostas

\footnotetext{
${ }^{21}$ Chamavam de "funcionários" apenas aquelas pessoas que trabalhavam para o dono de um empreendimento, sem ser "proprietário". Já "comerciante" era uma categoria mais genérica, podendo designar tanto o dono de loja quanto alguém que alugava a loja e também os funcionários.

${ }^{22}$ Certa vez um comerciante comparou a valorização da localização da loja com o "camelô", afirmando que este procurava se posicionar onde passavam mais pessoas, que veem que ele está ali. Assim acontecia com as lojas, quanto mais pessoas as vissem, melhor.

${ }^{23}$ Política de pacificação de favelas implementada pelo governo do estado do Rio de Janeiro. No período da pesquisa existiam UPPs nas proximidades do Cadeg: em Mangueira, Caju e Barreira/Tuiuti, em São Cristóvão.
} 
salsa, cebolinha, manjericão, tomilho, coentro, rúcula, alface, entre outros. As lojas do Cadeg são distribuídas por três andares, cada um deles com aproximadamente 30 metros quadrados. Ao entrarmos nelas, percebe-se que estão divididas, geralmente, em primeiro piso, onde vendem as mercadorias, mezanino (ou segundo andar), onde se localizam os escritórios, e terceiro piso, que é usado como depósito e também para outros fins, como cozinha ou lugar de descanso dos funcionários. Os pisos das lojas são cimentados, assim como os das ruas e avenidas. Algumas lojas usam marmorite vermelho em seu piso e paredes azulejadas até meia altura.

$\mathrm{O}$ fato de tanto as lojas quanto as ruas terem o mesmo tipo de piso faz com que elas tenham uma continuidade com o espaço de circulação do público. As entradas das lojas são cobertas por marquises, que foram colocadas no período de sua construção quando o mercado ainda não tinha a cobertura. As marquises, por serem rebaixadas, fazem com que as altas lojas (com um total dos três andares de aproximadamente 8 metros) tenham uma proporção mais próxima da escala humana. Muitos comerciantes aproveitam esse espaço a mais na entrada de suas lojas para expor as suas mercadorias lá. Eles empilham as frutas ou os legumes em formato de pirâmides, ou deixam a mercadoria dentro das caixas, que são sobrepostas. Os comerciantes, como o verdureiro Zé, ficam a maior parte do tempo na fronteira tênue entre a sua loja e a rua ou a avenida. Quando eles fecham a loja, apenas baixam as grades, que marcam sutilmente a ruptura com a rua, já que é possível ver, mesmo estando fechadas, o seu interior. 


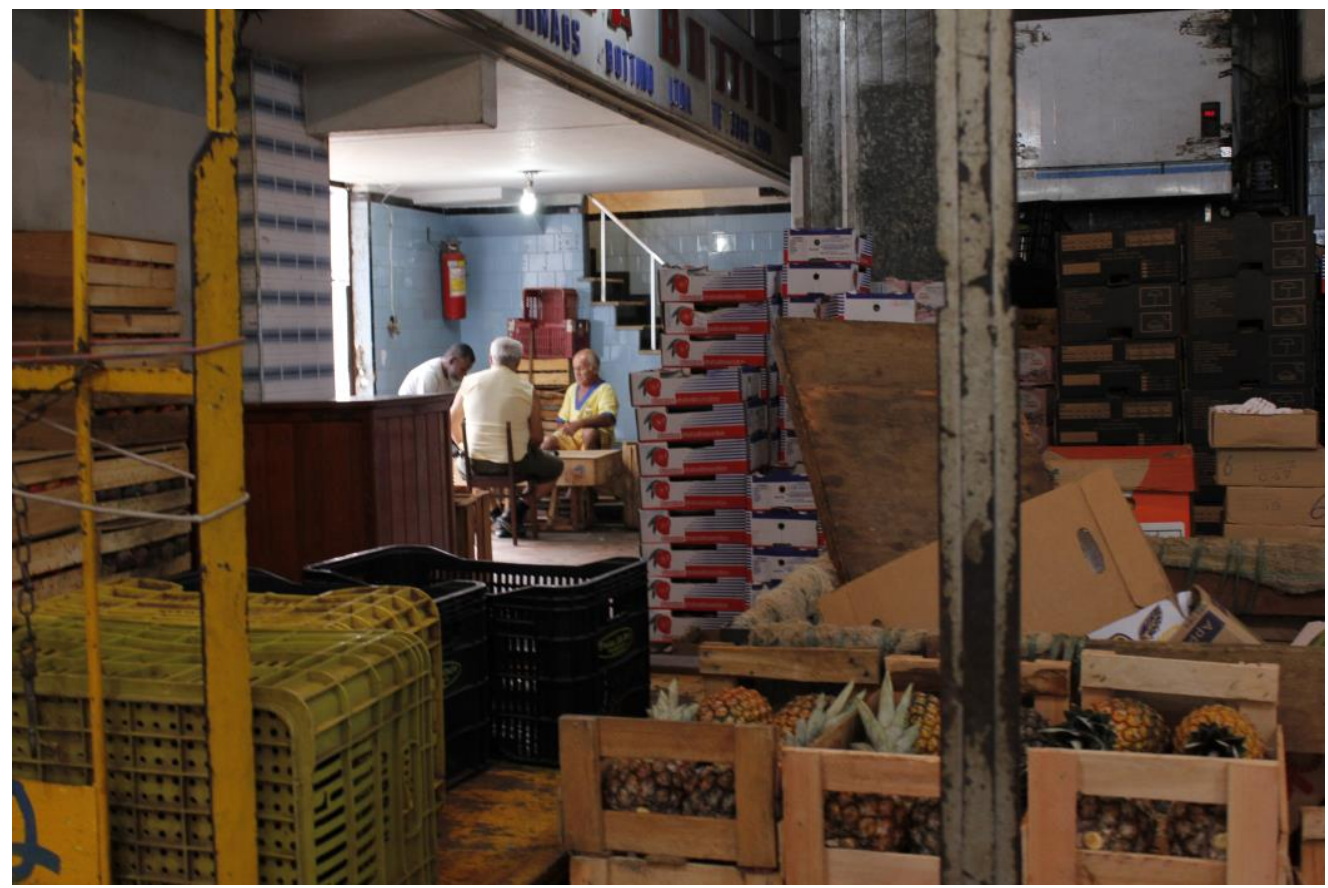

Comerciantes jogando cartas nos fundos da loja. Rio de Janeiro, manhã de 19 de novembro de 2011 (Fotografia: Nina Pinheiro Bitar)

A grande maioria dos comerciantes é homem, sendo os escritórios o principal espaço das mulheres, que trabalham na contabilidade, tonando-se quase invisíveis nos locais de vendas do mercado. Há também mulheres trabalhando no comércio, poucas com a venda a varejo de hortifrutigranjeiros e a maioria em lojas de bebidas. Já entre os clientes há uma grande quantidade de mulheres, quase no mesmo número que os homens. Alguns estudos apontam que o ambiente predominantemente masculino dos mercados é uma das peculiaridades de certos contextos (Bestor, 2004; Garcia, 1984, 1992; Geertz, 1979, entre outros). ${ }^{24}$

De acordo com os comerciantes, o trabalho é "muito pesado" para mulheres e os seus empregos na contabilidade são geralmente cargos de confiança, ocupados por pessoas da família ou amigos. Tal observação demonstra que algumas atividades do mercado estão de certa forma fechadas para pessoas que não fazem parte de suas redes de relações de confiança. Este é o caso da contabilidade, direcionada ao cálculo do fluxo de dinheiro. A responsabilidade desse cargo faz com que a pessoa que o ocupe seja considerada idônea e também alguém de "confiança".

\footnotetext{
${ }^{24} \mathrm{Na}$ pesquisa desenvolvida por Mintz $(1971,1987)$ no Haiti, ele observou o oposto, a predominância de mulheres como "intermediárias". Também foi o caso de Clark (1994) no contexto dos mercados do oeste africano.
} 
O horário, segundo os comerciantes, "é muito cansativo". O verdureiro Zé, por exemplo, chega ao Cadeg todos os dias às 20 horas, exceto aos domingos - o "dia de folga" dele e da maioria dos comerciantes do mercado. Ele vem nesse horário porque não gosta de andar pelas ruas de madrugada, apesar de morar próximo do mercado e ir para lá de Kombi. Ao chegar ao mercado, dorme no mezanino da sua loja até 1 hora da manhã, quando começa a colocar as caixas dos seus produtos na parte da frente de sua loja, organizando-os pelo seu tempo na loja, ou seja, as mercadorias mais "velhas" ou "maduras" são posicionadas à frente, e as que ainda estão "verdes" ou são "mais novas", atrás. A maioria dos comerciantes faz isso para que os produtos mais maduros sejam vendidos com maior rapidez, evitando que estraguem obrigando-os a jogá-los fora. ${ }^{25}$

Zé e a maioria dos comerciantes de venda a atacado e varejo iniciam as vendas às 2 horas da manhã. Os vendedores do mercado comumente se referem ao horário de início do funcionamento como manhã, e não madrugada. É o momento em que o dia deles começa, sendo um marco temporal importante. Zé permanece em pé ou sentado no carrinho em frente à sua loja. Quando os clientes chegam, ele os atende, coloca a mercadoria em sacolas de plástico ou bota as caixas de mercadorias em cima do carrinho do carregador para serem levadas até o veículo do comprador. Este outro serviço é realizado pelos carregadores, que negociam o preço diretamente com o cliente, variando entre $\mathrm{R} \$ 2$ e $\mathrm{R} \$ 5$. Depois de iniciar o trabalho, Zé apenas o interrompe para conversas com outros comerciantes e para o "lanche", às 4 horas da manhã, quando toma uma sopa de legumes num boteco próximo à sua loja.

Em torno das 13 horas, quando o "movimento" já vai diminuindo, ele recolhe as mercadorias que estavam na entrada da loja e coloca algumas delas no frigorífico localizado no segundo andar. Fecha as grades da loja, dando por encerrado o seu dia no mercado por volta das 14 horas. Ele almoça em sua casa e dorme, com a televisão ligada, de 16 às 19 horas. Reinicia então o ciclo, que é interrompido apenas pela sua

\footnotetext{
${ }^{25}$ Eles afirmaram que o mercado é mais movimentado no "verão" do que no "inverno". Há uma rede de catadores de lixo que vão ao Cadeg para pegar as mercadorias que são jogadas no lixo - muitas delas só tendo algum "defeito", mas estando em bom estado para o consumo, no entanto, não podendo mais serem comercializadas. Há uma procura dos clientes por mercadorias que estão "perfeitas", uma noção de "beleza" também, ou seja, sem rachaduras, amassados, arranhões ou furos. As mercadorias que estão estragadas vão imediatamente para o lixo. Eles jogam essas mercadorias nas lixeiras da área de carga e descarga, localizada nos fundos das lojas.
} 
"folga" no domingo, de 14 horas do sábado às 2 horas da manhã de segunda, quando reabre a sua loja.

Já o cerealista Jin trabalha há 15 anos no Cadeg. Começou numa loja de produtos orientais na Avenida Central do mercado, indicado por sua família, já que ele é filho de japoneses e, posteriormente, montou a sua própria loja rua 10.

Ao entrar em sua loja veem-se grandes potes de "cereais" dispostos na entrada, contendo arroz de vários tipos, como "multigrãos", "cateto", "branco", "integral", alguns tipos de feijão, grão de bico, farinhas, lentilha, ervilha, amendoim, castanha, entre outros. Há estantes de madeira em torno das paredes com potes menores de frutas secas, como damasco, uva, maçã, laranja e temperos "desidratados", como orégano, salsa e cebolinha. Ao fundo de sua loja há uma balança eletrônica, uma prensa para fechar os sacos de plástico contendo os produtos vendidos e um balcão onde são realizados os pagamentos. Em cima do balcão encontram-se um computador e uma calculadora.

No topo da parede esquerda de sua loja há uma imagem de São João. É comum ter imagens de santos nas lojas do Cadeg. O cerealista Jin explicava que tinha o santo em sua loja porque São João é um "santo trabalhador, que protege o meu trabalho". A categoria "trabalho" é fundamental para os comerciantes do mercado, muitas vezes expressa por ser um "trabalho difícil, pesado". E peso para eles tem tanto a ver com as caixas e os sacos de mais de 20 quilos que carregam como também com o horário de trabalho, principalmente nas madrugadas.

O horário, segundo ele, é "cruel”, mas "com tudo se acostuma". Ele abre sua loja às 3 horas da manhã e fecha ao meio-dia, no máximo. Ele considera ser esta uma vida difícil que implica um sacrifício específico, como todas as profissões. Ele sai do mercado às 12 horas, almoça em sua casa em Brás de Pina, dorme de 14 horas até as 19 horas, acorda para jantar, dorme novamente até 22 horas e depois se prepara para voltar ao trabalho. Segundo Jin, seus fornecedores são todos de São Paulo. Eles levam uma tabela com uma lista de produtos e Jin faz seus pedidos lá mesmo em sua loja, não sendo necessário sair do mercado para encomendá-los.

Ele explica que o mercado pode ser compreendido em função de seus diferentes horários, quando se observa a transformação que ele sofre ao longo do tempo. Nesse contexto, "tempo" se refere tanto ao desenrolar do dia, em seus distintos momentos de trabalho, quanto ao período da semana, que é marcado por um fluxo. 
A categoria "tempo" apareceu nos comentários dos trabalhadores do mercado como um demarcador de "movimento" de coisas e pessoas. O tempo, assim, está associado ao cotidiano, o dia a dia de trabalho, e à apropriação do espaço do mercado por diferentes "públicos” que terá o final de semana como um demarcador em relação aos dias úteis da semana.

Para Jin, o mercado vive mudanças, relacionadas às tarefas desempenhadas cotidianamente pelos vendedores e também pelos diferentes perfis dos consumidores que passaram a frequentá-lo recentemente. Pode-se dizer que as diferenças de "públicos" foram geradas pelo chamado de "enobrecimento" do Cadeg. Os comerciantes apontavam que havia nos últimos anos uma maior procura do mercado pelo chamado "público da zona sul”, zona da cidade concebida como "nobre" pelo imaginário de parcela da população.

Havia uma transformação no "movimento" conforme o horário. De madrugada as pessoas compravam grandes quantidades de alimentos. Os clientes que chegam mais tarde compram poucas coisas para suas casas e, finalmente, por volta do meiodia entram no Cadeg aqueles que vão para almoçar, ficando no mercado, em muitos casos, até as 17 horas.

Outros comerciantes apontaram que houve mudanças significativas na relação de fornecimento e de venda no mercado. Antônio Bernardino e Sérgio Umehara, trabalham na rua 15 e vendem hortifrutigranjeiros a atacado e varejo no Cadeg.

Atualmente, Bernardino e Sérgio contam com 37 funcionários em sua empresa particular no Cadeg. Eles abriram sua loja em 1994 e a mercadoria que vendiam, segundo Bernardino, era "colhida no dia" e entregue na noite do dia seguinte. A loja faz entregas com os seus cinco caminhões. Eles entregam "desde batata até fruta" para restaurantes na zona sul carioca. Apenas restaurantes pequenos vão até o Cadeg para comprar seus produtos, pois eles não contam com estoque para mercadorias em suas lojas. Geralmente os restaurantes estocam para dois dias, no máximo, conforme afirmou. Nas palavras de Bernardino, é "um trabalho grande, a gente procura ser organizado". Organização para ele significa cumprir os horários de entrega, garantir a qualidade da mercadoria, comprar por bons preços do fornecedor, o que influencia o seu preço final, que é mais barato. Ele também ressalta que os seus funcionários devem estar devidamente uniformizados, obedecer a essa organização para receber cesta básica, vale transporte, "porque é de lei, pagamos todos os direitos trabalhistas, 
nós não temos um centavo atrasado de nada. A gente procura manter a coisa dentro do sistema racional".

Bernardino explicou da seguinte forma o que considera o "sistema racional":

\begin{abstract}
Esse é o trabalho da gente, de segunda a segunda. Você sabe quantos feriados nós temos? Dia 25 de dezembro, $1^{\circ}$ de janeiro e terça-feira de Carnaval, só. Os outros feriados, dia santo, dia da República, 7 de Setembro, Sexta-Feira Santa, todos esses feriados nós trabalhamos. É como a natureza. A natureza não para de produzir porque é feriado, ela vai se renovando. O fruto vai crescendo, vai sendo colhido e não para, não para no feriado, continua, não é? E assim somos nós. A única diferença é que a gente para nesses três dias no ano. Também não há condição de trabalhar no dia 25 , Natal, e no dia 1 de janeiro, está todo mundo comemorando, não está comprando nada. Terça-feira de Carnaval não tem ninguém, o pessoal só quer samba. Essa é a nossa atividade, mas cada loja aqui dentro tem a sua atividade, tem a sua administração própria, seu ritmo de trabalho, seu esquema de trabalho.
\end{abstract}

Desta forma, o "sistema racional" está, segundo ele, intimamente ligado ao ritmo produzido pela "natureza", que "não para de produzir", continua se "renovando" e, portanto, eles também.

O comércio realizado no mercado assim é explicado por ele, obedecendo ao seguinte "sistema racional": encomendam e compram as mercadorias diretamente dos produtores; abastecem restaurantes, hospitais, hotéis, e até mesmo alguns comerciantes do Cadeg, fazendo a entrega em seus estabelecimentos; vendem na loja as mercadorias a varejo; e reiniciam o ciclo quando acaba o seu estoque. Esse ciclo é marcado pelo ritmo da natureza, sendo também ininterrupto.

\title{
"Esvaziamento" e construção de um "patrimônio" no Cadeg
}

Um fator fundamental de estruturação do tempo e do espaço do Cadeg, o que muitos comerciantes ressaltavam como as "mudanças" do mercado, foi a criação da Ceasa e o consequente esvaziamento do Cadeg na década de 70, apontada como seu grande concorrente. Houve nesse momento um grande esvaziamento do Cadeg, pois muitos comerciantes se mudaram para o novo mercado criado pelo governo. Segundo os comerciantes, o Cadeg era o maior abastecedor da cidade do Rio de Janeiro antes da inauguração da Ceasa, cujos principais clientes eram os grandes supermercados.

Os comerciantes ressaltavam que a década de 70 foi um marco temporal para o abastecimento da cidade e para a ressignificação do Cadeg. Segundo seus discursos, o 
advento da Ceasa foi um dos fatores que produziram "as mudanças" do mercado, que se manifestam no rearranjo dos tipos de negócios abrigados pelo Cadeg e em um novo perfil de clientela.

O tempo do mercado era, assim, estruturado em cinco períodos distintos e que remetiam também a outros espaços: fim do Mercado Municipal da Praça XV de Novembro; criação do Cadeg; antes da fundação da Ceasa; depois da Ceasa; e agora como novo Mercado Municipal do Rio de Janeiro.

O comerciante Emanuel Germano Rodrigues Caridade, português, apontou o relacionamento que o Cadeg tinha com a Ceasa. Sua loja de venda de frutas a atacado e varejo está localizada no final da rua 10. Os seus maiores clientes são os mercadinhos e os chamados "fornecimentos" (que abastecem hotéis, restaurantes, casas de saúde, hospitais), que chegavam ao mercado logo que sua loja abria.

O senhor Germano morava no Minho (Portugal) e chegou ao Rio de Janeiro em 1963, quando tinha 16 anos. Ele é considerado "antigo" no Cadeg e já foi diretor do Cadeg. Ele contou que, quando ainda morava em Portugal, seu tio enviou-lhe a "carta de chamada", que apresentou para entrar no Brasil. Germano já trabalhava em Portugal com venda de calçados. Logo que chegou ao Brasil, ele trabalhou em "serviço de restaurante" e também ajudava o seu tio, que era carregador no Cadeg. Germano conseguiu emprego numa loja do Cadeg já no ano seguinte, em 1964, por indicação de seu tio. Segundo ele: "então, a minha vida desde 64 é aqui. Eu moro mais no mercado do que em casa. Mas adoro! Chego aqui todo dia à 1 hora da manhã e vou embora daqui a pouco [9 horas]".

Quando começou a trabalhar na loja, foi imediatamente promovido e depois se tornou sócio. Ele afirmou orgulhoso que nunca faltou um dia de trabalho, nunca “ficou doente". Desde então, há 49 anos, seu cotidiano obedece à mesma rotina: "a minha vida é essa, uma vida de imigrante, como a gente falou, de pobre imigrante". Ele chega em sua casa às 11 horas e fica "liberado" para dormir até as 23 horas, porém, segundo Germano, "cansa, eu me sinto esgotado, porque esse horário é cansativo". Depois retorna ao mercado, dando prosseguimento ao seu trabalho.

Ele ressaltou que o Cadeg, na época de inauguração da Ceasa, sofreu com a diminuição drástica de clientela. Germano dividiu o tempo do Cadeg em "duas épocas": antes e depois da fundação da Ceasa. Houve nesse momento um grande "esvaziamento" do Cadeg, pois muitos comerciantes se mudaram para o novo 
mercado criado pelo governo. Segundo Germano, antes "era um tumulto no Cadeg, não havia como se movimentar, depois que o Ceasa veio, houve uma vazante muito grande, passamos uns tempos difíceis aqui”.

Germano relembra que, no dia em que inauguraram o Ceasa, "não apareceu uma viva alma, o mercado ficou deserto. Foi a pior época, uns cinco anos de sufoco". Ele contou que teve vontade de chorar nesse dia, mas "aos poucos foi voltando a clientela e nós estamos sobrevivendo com dificuldade, porque difícil está para todos". Germano apontou que na época da inauguração da Ceasa muitos comerciantes venderam suas lojas e foram para lá, mas ele permaneceu em sua loja porque:

Essa loja é minha, meu patrimônio, e todas essas lojas são patrimônio de cada um. O governo não tem nada aqui, não investiu em nada. A Ceasa, não, a Ceasa é capital do governo. Aqui não, aqui é particular, cada um tem a sua loja, ou duas: é dono, é proprietário.

Muitos comerciantes afirmam: "aqui já é um patrimônio nosso". Eles se sentem de certa forma também "donos" do mercado e, por isso, muitos permaneceram ali, mesmo com o brutal esvaziamento na década de 70. Como já havia um histórico de fechamento de mercados, como aconteceu com o antigo Mercado Municipal da Praça $\mathrm{XV}$, muitos deles optaram por permanecer no Cadeg. Pode-se dizer que o processo de formação de patrimônio é traduzido pela categoria "colecionamento", cujo efeito é a demarcação de um domínio subjetivo em oposição a outro (Gonçalves 2003).

Eles tinham a liberdade de montar o negócio que quisessem no Cadeg, desde que fosse "idôneo". Qualquer pessoa física ou jurídica podia comprar uma loja lá e depois vendê-la. Bastava o comerciante pagar o condomínio do Cadeg, além das taxas, o IPTU e suas contas. Entretanto, na Ceasa, tratava-se de "locação", e "ninguém pode dizer que é dono de box, é dono da firma; aquilo é do governo do estado".

O fato de a Ceasa ter sido criada também possibilitou, de certa forma, a formação de uma noção de "patrimônio" centrada ideia de "propriedade". Para Gonçalves (2003), "patrimônio" pode ser compreendido como uma categoria de pensamento que está vinculado, neste caso, a uma materialidade, mas também às relações sociais e simbólicas articuladas pelo processo de construção do mercado. 
Para os comerciantes, serem os "donos", os "proprietários" das lojas fazia com que "nenhum governo pudesse tirar isso" deles, como aconteceu na década de 60. Com a criação da Ceasa, produziram uma noção de alteridade, ao pensarem o próprio patrimônio em oposição ao patrimônio da Ceasa que, do ponto de vista deles, seria do governo. Ter uma loja era um fator que englobava também diversas esferas da vida desses comerciantes, ampliando, assim, sua noção de patrimônio. Para eles, trabalhar na Ceasa poderia significar: "o governo chega lá e diz assim: 'olha, vocês têm 30 dias, 60 dias para vocês saírem daqui, 90 dias'. Tem que sair porque a loja é dele [do governo]".

Em função de alguns comerciantes serem donos dos seus empreendimentos, de possuírem o seu "patrimônio", era o maior motivo de permanecerem no Cadeg. Patrimônio aqui pode ser entendido como sinônimo de "propriedade", mas tal conceito também engloba toda a vida cotidiana que eles construíram nesse mercado, não se restringindo somente ao seu espaço físico. Alguns dos chamados "funcionários", que não são proprietários de lojas mas trabalhavam para elas, também permaneceram no mercado após o seu esvaziamento. São redes de relações constituídas dentro do mercado guiadas pelo cotidiano das pessoas que ali convivem.

Os comerciantes apontam que a Ceasa vendia com melhores preços porque o produto não precisava passar pela loja, como acontecia no Cadeg. Por isso, o preço da mercadoria na Ceasa era menor, já que os comerciantes de lá não necessitavam pagar as despesas de infraestrutura, responsabilidade social e impostos. Mas "ter uma loja", para eles, era importante, mesmo que para isso tivessem que repassar as despesas para o preço final do produto. Muitos comerciantes do Cadeg compravam seus produtos diretamente da Ceasa, para assim revendê-los no mercado.

A Ceasa, assim, é o grande marco temporal para os comerciantes após a inauguração do Cadeg, pois foi a partir de sua criação que o mercado passou a ter outros tipos de comércio por causa de seu esvaziamento, o que também contribuiu para o seu atual "enobrecimento".

Outra perspectiva sobre o chamado "esvaziamento" ou "vazante" do Cadeg foi fornecida pelo senhor Orlando Pereira. Ele é português, natural de Viseu e aposentado. Chegou ao Brasil em 1961, aos 15 anos, e seu primeiro emprego foi na Padaria Capital, na rua São Luiz Gonzaga, próxima ao Cadeg. Ele entregava pão nos bares do Cadeg e começou a trabalhar no mercado numa loja chamada Lavourinha 
Princesa Ltda., o seu primeiro emprego no mercado, onde vendia batata, cebola e "legumes" em geral.

Ele conseguiu o emprego lá por intermédio de um tio seu que tinha uma quitanda na rua Benjamin Constant, no bairro do Catete, Rio de Janeiro. Seu tio comprava os produtos no Cadeg e apresentou-o aos donos da loja Lavourinha. Assim, ele iniciou sua vida no mercado, trabalhando por 11 anos como empregado. Depois lhe deram sociedade, ficando com $25 \%$ da loja (que era localizada na rua 9, loja 16). Fecharam a loja depois que surgiu a Ceasa e ele foi trabalhar sozinho na Casa Orlando Legumes Ltda., rua 11, loja 15, onde ficou por 30 anos. No período da pesquisa ele tinha um total de cinco lojas, e uma parte da sua renda vinha do aluguel delas.

Orlando já estava aposentado, mas ajudava os seus filhos no comércio. Parte de suas lojas foi alugada e outras eram usadas por seus filhos. Seus filhos estavam, portanto, dando continuidade ao seu trabalho no mercado, mas com uma atividade diferenciada da que seu pai exercia. Era comum que os filhos permanecessem no mercado, ficando no lugar de seus pais, entretanto, apenas observei a continuidade entre os homens, já que dificilmente as filhas ali trabalhavam.

Segundo ele, com a criação da Ceasa, "o mercado foi quase a zero, quando foi todo mundo pra lá. Foi um impacto muito grande. A freguesia foi pra lá toda, $90 \%$ foram pra lá, para o Ceasa". Orlando apontou que, com o esvaziamento do mercado, os produtos estragavam e o preço dos imóveis ficaram desvalorizados.

A partir da diminuição dos preços dos imóveis, muitos comerciantes aproveitaram para comprá-los, como ele o fez. Com o esvaziamento, diferentes tipos de negócios entraram no mercado porque, segundo ele, "antigamente" no Cadeg só vendiam legumes, frutas e folhagens, mas depois da criação da Ceasa surgiram outros ramos de comércio, como escritórios, firmas importadoras e exportadoras, floristas, além de ter aumentado exponencialmente o número de restaurantes. Orlando considerava que, em função do esvaziamento do Cadeg e com a diversificação das lojas, o mercado "mudou de estilo", gradativamente tornou-se um "polo gastronômico" e o maior distribuidor de flores do estado do Rio de Janeiro.

Antes da Ceasa, disse Orlando, no Cadeg "era muito movimento", os supermercados Mar e Terra, Disco, Casa da Banha, Sendas, os pequenos supermercados, os quitandeiros e os feirantes compravam suas mercadorias lá. Mas o Cadeg estava, na época, ficando "pequeno", apontou. 
Ele afirmou que, quando a Ceasa surgiu, houve um boato de que venderiam o mercado para o governo para ser transformado em um presídio, mas informa Orlando:

A gente fez o capricho do trabalhar e fazer frente a Ceasa também. [...] depois é que foi levantando, que foi surgindo. Os que ficaram aqui se empolgaram mais um pouquinho: "não vamos deixar cair o mercado, vamos trabalhar para não cair". Para não cair mais, porque já estava no fim.

Orlando explicou que com o esvaziamento do Cadeg surgiu a comercialização de flores, que preencheu o "vazio" deixado pela Ceasa. Foi nesse momento de entrada do "ramo das flores" no mercado que um dos filhos de Orlando, André, comprou uma loja localizada próxima ao galpão das flores, na última rua do Cadeg, para comercializar "produtos de jardinagem". Segundo Orlando, seu filho percebeu que o comércio de flores estava crescendo e criou a sua loja num "ponto que era bom para flor", foi uma "oportunidade".

Agostinho Gomes Ribeiro, comerciante do Cadeg, também abordou a questão da criação da Ceasa como o grande "marco" do Cadeg. Ele é português, dono de uma loja que vende batatas e cebolas ${ }^{26}$ localizada na Avenida Central, e trabalha desde os 13 anos no Cadeg.

O pai de Agostinho era carregador no Mercado Municipal da Praça XV, indo depois para o Cadeg, onde posteriormente abriu uma loja. Agostinho também ressaltou que o Cadeg era o maior fornecedor dos supermercados no "tempo" antes da Ceasa:

\begin{abstract}
Era uma loucura. Todos os supermercados compravam aqui. Então, isso daqui era uma loucura. Nesse paredão [Praça geral] daqui encostava o Disco, Sendas. Aqui, na época, entravam 50 toneladas de cebola. Você não conseguia nem andar aqui dentro. Porque na época não tinha tanto carro particular. [...] Só entrava praticamente caminhão. Pouca gente tinha carro de passeio, hoje qualquer família tem dois, três carros, mas antigamente era difícil, era mais difícil.
\end{abstract}

Ele ressaltou o período de "prosperidade" do Cadeg, que foi por mais de 10 anos um dos maiores abastecedores da cidade. Já quando a Ceasa abriu, as coisas mudaram: "eu me lembro que, no dia em que a Ceasa abriu, eu cheguei aqui com meu pai e não tinha uma viva alma aqui dentro. Só tinha os lojistas [risos]. É sério, só tinha

\footnotetext{
${ }^{26}$ Ele também vendia verduras, legumes, arroz, óleo, farinha, ovos, alho.
} 
os lojistas". De acordo com ele, todos os fregueses foram comprar na Ceasa, mas ele não fechou sua loja, permanecendo no Cadeg.

\begin{abstract}
Muita gente foi, mas teve aí uma força, alguns atacadistas mais fortes resolveram ficar e a gente está aqui até hoje. Nenhum deles quis sair do Cadeg. Isso daqui é nosso! As lojas aqui são nossas, na Ceasa, não, as lojas são do governo. O governo cisma de te mandar embora, você perde tudo. Aqui não, cada um fica com a sua loja - quem tem, e as outras são alugadas. Tenho três aqui alugadas, e mais duas. É uma coisa tua, um patrimônio teu. Eu tenho três lojas próprias alugadas para terceiros. Tenho duas onde eu trabalho, e aí eu pago aluguel. [...] Mudou um pouquinho. Hoje, quem vem aqui no Cadeg é a parte de varejo e a parte de tratamento de restaurante. Antigamente os feirantes eram todos aqui, pequenos mercados, grandes supermercados, tudo aqui. Era Casa da Banha, era Disco, era Mar e Terra, eram todos os fornecimentos. Então, basta dizer que aqui entravam 40, 50 caminhões de batatas, hoje não, entram três, quatro no máximo. Porque hoje aqui, isso daqui virou o quê? Virou um varejo.
\end{abstract}

Ainda segundo Agostinho, na época de criação da Ceasa:

\begin{abstract}
Aqui aconteceu da seguinte maneira. Sabe como é, tudo é novidade. O pessoal de início foi para a Ceasa. Mas aquele negócio, a Ceasa, é muito grande. Então, para você que vai comprar muita coisa, no nível de caminhão fechado, quantidade grande, tudo bem. Agora, aquele freguês que vai comprar pouca coisa, o cara se desgastava muito. Quer comprar uma caixa de tomate, vai aqui, quer comprar batata, tem que ir lá, no outro pavilhão, quer comprar uma laranja, tem que ir lá no outro pavilhão. Então, o pessoal passou a ir uma vez, duas e começou a voltar para cá. A pessoa vai para conhecer... Aqui é mais centralizado. Nós temos o Centro aqui do lado, Niterói aqui do lado, Linha Amarela, Barra ali do lado, Tijuca... o que ajuda muito o Cadeg é esse ponto de acesso. Tem aqui a Ponte Rio-Niterói, tem a Linha Amarela, a Avenida Brasil, tem o Centro. Então, fica muito bem centralizado aqui. É isso que ajuda até hoje o Cadeg.
\end{abstract}

Agostinho aponta assim para o primeiro processo de ressignificação do Cadeg após a abertura da Ceasa. O mercado deixava de atender a clientes que compravam grandes quantidades, mas paulatinamente iria recuperar seus fregueses interessados em compras de menor porte e de produtos mais qualificados.

A fala de Agostinho está voltada para dois fatores que contribuíram para o retorno dos clientes. Para ele, o Cadeg era menor do que a Ceasa, e a distribuição dos diversos tipos de produtos não eram feitas por pavilhões, como acontecia neste último. Isso facilitava o comprador que tinha à sua disposição uma variedade de produtos em uma área menor. Agostinho, assim como outros comerciantes, também ressaltava o posicionamento central do mercado, tornando-o mais acessível do que a Ceasa. O Cadeg está localizado a cerca de 20 minutos do centro da cidade, enquanto a Ceasa fica aproximadamente a 50 minutos. 
Os comerciantes explicavam que um dos fatores de permanência de clientes que compram no Cadeg é o fato de este mercado ser mais "aconchegante e seguro", apesar de a Ceasa ter realmente um melhor preço para os produtos. Apontavam que em certos dias a Ceasa era "impraticável”, por ser muito cheia. Além disso, o local era visto como "perigoso", com assaltos dentro e fora, além de ser um mercado muito grande, com vendedores muitas vezes sem paciência para atenderem aos clientes. Para eles, o Cadeg é um pouco mais caro, mas "nós temos seguranças, você pode vir com dinheiro no bolso, entrou aqui na rampa, sinta-se seguro. “Ah, mas é cercado de morros e favelas". Esquece isso. Nunca houve um assalto aqui no meio da rua. Nunca".

"Segurança", para muitos comerciantes, não significava somente prevenir roubos, violências e contravenções no Cadeg. Eles apontavam que a Ceasa não oferecia segurança não apenas no sentido de ter assaltos ou violência física, mas também por não oferecer a "confiança" de que o produto não seria adulterado. Às vezes acontecia de comprarem, por exemplo, laranjas na Ceasa e encontrarem, segundo eles, pedras no meio, alterando o peso do produto.

Assim, o Cadeg se reconfigurou como um atravessador das mercadorias oferecidas pelo Ceasa, quando não as compravam diretamente dos produtores. Foi formada uma outra rede de trocas comerciais que possibilitou a sua permanência nesse período de crise. Os comerciantes que compravam suas mercadorias na Ceasa faziam a pré-seleção dos produtos para os vender aos seus clientes com uma melhor qualidade. 


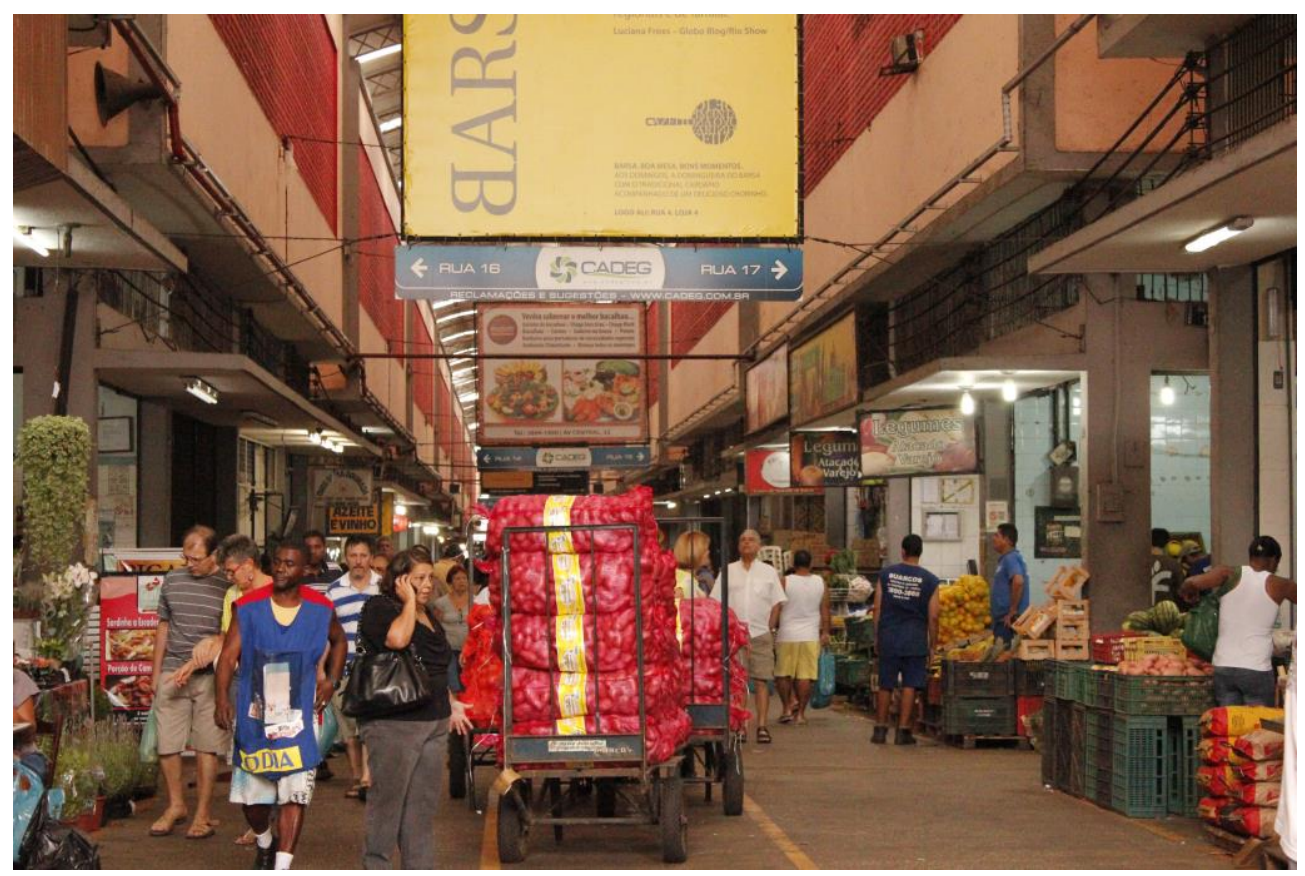

Carrinhos estacionados na Avenida Central. Rio de Janeiro, manhã de 10 de novembro de 2012 (Fotografia: Nina Pinheiro Bitar)

Além dos vínculos com os comerciantes da Ceasa, também são estabelecidas relações de trocas internas entre os próprios vendedores do Cadeg. Muitos comerciantes do Cadeg compram os produtos lá mesmo no mercado e os revendem. Já no caso dos produtos importados (frutas secas, por exemplo) de outros países, como Estados Unidos, África do Sul, Chile e Argentina, entre outros, são encomendados diretamente na Ceagesp (Companhia de Entrepostos e Armazéns Gerais de São Paulo), pois já se trata de um “esquema global”.

Observando as práticas de cada comerciante, vale destacar a sua característica enquanto "comprador-vendedor", formulada por Geertz (1979) em sua análise do contexto do comércio marroquino. Para Geertz os comerciantes que estavam no mercado vendendo os seus produtos também eram compradores, estabelecendo, através de sua rede de relações, os laços de comércio. Mais ainda, a relação existente entre os comerciantes do Cadeg e os da Ceasa revela o que Malinowski (1957) chamou de "sistema de mercados", reconhecendo que os mercados não estão isolados, mas articulados entre si e vinculados à forma de vida dos comerciantes que neles trabalham. 


\section{Considerações finais}

Através da observação direta das práticas dos agentes desse mercado, percebi que classificações temporais eram estruturadoras do cotidiano do Cadeg. Este artigo buscou demonstrar que o espaço do mercado passa por uma constante reinvenção, não sendo apenas um reflexo de concepções urbanísticas ou políticas de abastecimento aplicadas à cidade. Ou seja, os mercados, assim como as pessoas envolvidas nas suas práticas cotidianas e os objetos que lá circulam, "agem" (Gell, 1998) nas cidades, não sendo apenas produtos ou reflexos de políticas públicas. Existe um diálogo estabelecido através de múltiplas "ressonâncias", pois tanto as políticas públicas ressoam no cotidiano do mercado quanto o mercado transforma esse espaço urbano.

Desde seu projeto da construção, o Cadeg espelhou as transformações que aconteciam na "cidade". A sua fundação foi resultado da extinção do Mercado Municipal da Praça XV de Novembro e da mobilização de um grupo de comerciantes que perdeu o seu local de trabalho na década de 60. Houve, então, uma concepção urbanística que alterava o espaço da cidade através da construção do Elevado da Perimetral, que atravessou o antigo mercado e a sua consequente demolição. Nesse mesmo período, os comerciantes se organizaram para a construção do Cadeg, um mercado privado. O novo mercado transformava a configuração do espaço urbano, construindo no bairro de Benfica um centro de abastecimento que alterava, assim, o fluxo de pessoas e de mercadorias na cidade. ${ }^{27}$

Pode-se dizer que o Mercado Municipal da Praça XV de Novembro ainda se faz presente em diversos aspectos no Cadeg. Ele, além de permear as narrativas dos comerciantes, também estrutura a própria forma de trabalho dos agentes do Cadeg. Os comerciantes antigos ou os fundadores constantemente descreviam o seu trabalho desempenhado de maneira semelhante àquela no Mercado Municipal da Praça XV de Novembro, reproduzindo no Cadeg a estrutura formada anteriormente nesse mercado.

O próprio nome do Cadeg pressupõe marcadores temporais. Quando os arquitetos ainda faziam o projeto do mercado em 1959, o Rio de Janeiro era Capital

\footnotetext{
${ }^{27}$ Atualmente o Cadeg faz parte do Polo Comercial Largo de Benfica, criado pelo decreto 32.424, assinado pelo prefeito Eduardo Paes em 22 de junho de 2010. Polo de Benfica faz parte do programa Polos do Rio, que tem como objetivo a "promoção das vocações locais das diversas regiões da cidade do Rio de Janeiro, por meio do estimulo à atividade econômica e consolidação de espaços atraentes de convivência para os cariocas e turistas" (Portal Polos do Rio).
} 
Federal do país, assim, o primeiro nome do mercado seria CADF (Centro de Abastecimento do Distrito Federal). Em 1960, o Rio de Janeiro deixou de ser a Capital Federal, sendo fundado o estado da Guanabara. Ao inaugurarem o mercado, em 1962, o Cadeg passou a carregar em seu nome "estado da Guanabara", chamandose Centro de Abastecimento do Estado da Guanabara. Em 1975, foi dissolvido o estado da Guanabara e fundados o estado e a cidade do Rio de Janeiro. Contudo, os diretores do Cadeg decidiram permanecer com o nome com o qual o mercado já era reconhecido. Essas mudanças do nome do mercado mostram que há uma a relação direta com as alterações nas categorias jurídicas que determinavam as fronteiras espaciais e as concepções de funcionamento das gestões públicas do município e do estado. Isto fica evidente na alteração do nome do mercado: primeiramente, "Distrito Federal”, depois, "Estado da Guanabara". Por outro lado, a opção por manter em seu nome "Estado da Guanabara", mesmo após a sua extinção, produziu um demarcador temporal que associava o Cadeg a um momento específico da cidade: o período de sua fundação.

Em 2012, por decreto do prefeito, o nome do mercado foi alterado novamente, agora para "Cadeg - Mercado Municipal do Rio de Janeiro"28. Esse decreto municipal concretizou juridicamente diferentes concepções de espaços e temporalidades, presentes principalmente nos discursos dos chamados "fundadores" do Cadeg, que entendem o Cadeg como uma "continuação" do Mercado Municipal e um reflexo das transformações pelas quais a cidade passou, ali condensadas metaforicamente no seu novo nome.

Os comerciantes consideravam o Cadeg um "patrimônio privado". Segundo eles, tal "patrimônio" foi construído com o seu "próprio esforço", que se manifesta através da categoria "trabalho". Existe então nos seus discursos uma dupla valorização: tanto do mercado enquanto sua "propriedade" quanto do "esforço" ou do “trabalho" empenhado por eles na construção e na manutenção do Cadeg. Desse modo, a concepção de patrimônio dos comerciantes é concebida como um "fato social total" (Gonçalves, 2003, 2007) que compreende valores de posse e também as diversas práticas cotidianas voltadas para a produção e a sustentação do Cadeg.

\footnotetext{
${ }^{28}$ Vale lembrar que o Mercado Municipal da Praça XV de Novembro carregava em seu nome o dia da proclamação da República no Brasil, que nomeava a praça onde era localizado.
} 
Esta noção de patrimônio foi fortalecida através da oposição do Cadeg a Ceasa. Com a criação das políticas das centrais de abastecimento no período da ditadura, surgiu na década de 70 a Ceasa, um "outro" do Cadeg. Nesse período, os comerciantes fortaleceram a noção de mercado como seu patrimônio, sua "propriedade", muitos deles permanecendo no Cadeg, "nas suas lojas", mesmo com o abrupto "esvaziamento" e a decadência sofridos com a concorrência da Ceasa. Os comerciantes permaneceram no Cadeg porque as suas lojas eram o seu patrimônio e não poderiam, assim, ser "expulsos" do seu local de trabalho, como aconteceu na década de 60 no Mercado Municipal da Praça XV de Novembro. Já a Ceasa era um “patrimônio do estado", onde as regras eram ditadas pela administração pública.

Havia uma ideia de patrimônio "familiar", que era expressa por muitos filhos de comerciantes que assumiram a administração das lojas de seus pais, mantendo sua atividade no comércio, mesmo com as dificuldades enfrentadas. Os comerciantes afirmavam que o mercado era "igual cachaça", um "vício" que era passado também para os seus "herdeiros", pois eles eram criados ali, no cotidiano de intenso trabalho.

Outro aspecto importante são as concepções de "mudança" desenvolvidas pelos agentes do mercado em função do "vazio" deixado pela criação da Ceasa. O processo de "enobrecimento" era percebido pelos comerciantes através da categoria "mudança", um processo amplo que englobava desde as narrativas dos fundadores até o atual momento de ressignificação de suas atividades. Assim, meus interlocutores afirmavam constantemente que o "Cadeg passava por intensas mudanças". Posso dizer que no início da pesquisa, em 2011, o Cadeg era praticamente desconhecido pelo chamado "novo público", o "público zona sul", mas que hoje faz parte de uma rotina de "entretenimento" de muitos moradores da cidade.

Recentemente, os chamados "festivais gastronômicos" organizados pelos restaurantes do mercado se tornavam cada vez mais frequentes, fazendo com que o Cadeg fosse amplamente divulgado pela mídia, atraindo mais o "novo público". Ao mesmo tempo, aconteceu no Cadeg uma maior diversificação dos tipos de comércio, principalmente aqueles voltados para o setor gastronômico, com a inauguração frequente de novos restaurantes, bistrôs, cafés, além de lojas de venda de bebidas importadas. O setor do comércio de hortifrutigranjeiros também acompanhava essa mudança do mercado, criando novos turnos de trabalho e adaptando os seus negócios para a venda de produtos a varejo, além do comércio já existente de venda a atacado. 
As multiplicidades de sentidos engendrados no Cadeg estão relacionadas à diversidade dos tipos de atividades (venda de flores, hortifrutigranjeiros, comidas, bebidas etc.) que lá são desenvolvidas. Como observei, essas atividades estão permeadas por relações de parentesco, concepções de natureza e cultura (a sazonalidade de flores e hortifrutigranjeiros), concepções de cidade e de mercado, categorias de tempo (expressas na extinção e criação dos novos mercados e nos horários de trabalho), técnicas corporais, categorias de gênero, estética, entre outras. $\mathrm{O}$ mercado realiza mediações fundamentais entre diversos aspectos da vida social e imaginários sobre a "cidade". Com o acompanhamento do cotidiano do mercado, o Cadeg revelou-se um mediador de relações sociais e simbólicas, materiais e um importante um mediador das categorias temporais e espaciais.

\section{Referências}

BESTOR, Theodore C. Tsukiji: The Fish Market at the Center of the World. California: University of California Press, 2004.

."Market places: Tokyo and global tuna trade". In: Low, M. Setha \& Laurence-Zuñiga (Orgs.) The anthropology of space and place. Oxford: Blackwell publishing, 2003.

BIDOU-ZACHARIANSEN, C. "Introdução". In: Bidou-Zachariansen, C.; Hiernaux-Nicolas, D.; Rivière d'Arc, H. (orgs.) De volta à cidade: dos processos de gentrificação às políticas de "revitalização" dos centros urbanos. São Paulo: Annablume, 2006.

BITAR, Nina Pinheiro. “O maior mercado do mundo!”: uma etnografia do Cadeg, o novo Mercado Municipal do Rio de Janeiro. Tese de doutorado em Antropologia Cultural, Universidade Federal do Rio de Janeiro, 2014.

CARRIER, James. "Introduction". In: Meanings of the Market - The Free Market in Western Culture. Oxford \& New York: Berg, 1997, pp.1-67.

CLARK, Garcia. Onions are my husband. Chicago/Londres: The University of Chicago Press, 1994.

DURAND, Gilbert. A imaginação simbólica. Lisboa: Edições 70, 1993. As Estruturas Antropológicas do Imaginário. São Paulo: Martins Fontes, 2002.

DURANDO, Vanessa. Balôn: Um Mercado Popular. Curitiba: Dissertação apresentada ao Programa de Pós-Graduação em Antropologia Social da Universidade Federal do Paraná, 2010.

ECKERT, Cornelia e ROCHA, Ana Luiza Carvalho da. "Imagens do tempo nos meandros da memória: por uma etnografia da duração". In: Iluminuras, Número 4. Porto Alegre: BIEV, 
PPGAS/UFRGS, 2000a.

"Os jogos da memória". In: Iluminuras, Número 12. Porto Alegre: BIEV, PPGAS/UFRGS, 2000b.

ECKERT, Cornelia e ROCHA, Ana Luiza Carvalho da. (org). Etnografia de rua. Estudos de antropologia urbana. Porto Alegre: UFRGS Editora, 2013a.

. Etnografia da Duração. Porto Algre: Marcavisual, 2013b.

. Antropologia da e na cidade. Interpretações sobre as formas de vida urbanas. Porto

Algre: Marcavisual, 2013c.

FERRETI, Mundicarmo. De Segunda a Domingo Etnografia de um Mercado Coberto - Mina, uma religião de origem africana. São Luís: Serviço de Impr. e Obras Gráficas do Estado, 1985.

FERRETI, Sergio (org.) Reeducando o olhar: estudos sobre feiras e mercados. São Luiz: Edições UFMA; PROIN(CS), 2000.

FILGUEIRAS, Beatriz Silveira Castro. Do Mercado Popular ao Espaço de Vitalidade: o Mercado Central de Belo Horizonte. Dissertação em Planejamento Urbano e Regional da Universidade Federal do Rio de Janeiro - UFRJ, 2006.

FONSECA, Maria Cecília Londres. O Patrimônio em processo: trajetória da política federal de preservação no Brasil. Rio de Janeiro: UFRJ/ IPHAN, 2005.

GARCIA, Marie-France. O Bacurau. Tese de mestrado em Antropologia Social, UFRJ, Museu Nacional, 1977.

. Feira e trabalhadores rurais: As feiras do Brejo e do Agreste Paraibano. Tese de Doutoramento. PPGAS-UFRJ. Museu Nacional. Rio de Janeiro, 1984.

. "Espace du marché et mode de domination". In: Études Rurales,1993; 131-132: 5772.

. "O segundo sexo do comercio: camponesas e negócio no Nordeste do Brasil". In: Revista Brasileira de Ciências Sociais, nº19. Rio de Janeiro, ANPOCS, 1992.

. "A construção social de um mercado perfeito: o caso de Fontaines-en-sologne". In: Estudos Sociedade e Agricultura, 20, abril 2003, pp. 5-44.

GASPAR, Samantha dos Santos. "Gentrification: processo global, especificidades locais?” In: Ponto Urbe (http://www.pontourbe.net/edicao6-artigos/107- gentrification-processo-globalespecificidades-locais), Ano 4, agosto de 2010

GEERTZ, Clifford. "Suq: the bazaar economy in Sefrou.” In: Clifford Geertz, Hildred Geertz \& Lawrence Rosen (orgs.) Meaning and order in Moroccan society - Three essays in cultural analysis. Pp.123-310. Cambridge: Cambridge University Press, 1979.

GELL, Alfred. "The origination of the índex", "The critique of the índex" e "The distributed person". In: Art and Agency: an anthropological theory. Oxford: University Press, 1998. 
"The Market Wheel: Symbolic Aspects of an Indian Tribal Market". Man, New Series, Vol. 17, No. 3 (Sep., 1982), pp. 470-491.

GLASS R. Aspects of Change, in Centre for Urban Studies. London: Aspects of GONÇALVES, J. R. S. "O patrimônio como categoria de pensamento". In: Memória e Patrimônio: ensaios contemporâneos. Regina Abreu e Mário Chagas (org.). Rio de Janeiro: DP\&A, 2003.

Antropologia dos Objetos: coleções, museus e patrimônios. Rio de Janeiro: Coleção Museu Memória e Cidadania, 2007.

"A Crise do Patrimônio: da retórica da perda à reconstrução permanente". In: 32 Encontro Anual da ANPOCS: Patrimônio, Memória e Sociedade: tendências e desafios, 2008. GORBERG, Samuel; FRIDMAN A., Sergio. Mercados do Rio: 1834-1962. Rio de Janeiro: S. Gorberg, 2003.

HEIDEGGER, Martin. "Construir, habitar, pensar". In: (Choay, Françoise org.) $O$ Urbanismo. São Paulo: Editora Perspectiva, 1992.

INGOLD, Tim. "Building, dwelling, living: how animals and people make themselves at home in the world". In: The perception of the environment: essays in livelihood, dwelling and skill. Routledge, London, 2000, pp. 172-188.

LA PRADELLE, Michèle. Market Day in Provance. Chicago: Universitty of Chicago, 2006.

LEITÃO, Wilma Marques (org.). Ver-o-Peso: estudos antropológicos no mercado de Belém. Belém: UFPA, 2010.

LEITE, Rogério Proença. Contra-usos da cidade: lugares e espaço público na experiência urbana contemporânea. Campinas: Ed. Unicamp, 2004.

MALINOWSKI, Bronislaw; DE LA FUENTE, Julio. "La Economía de un Sistema de Mercados en México - Un ensayo de Etnografía Contemporánea y Cambio Social en un Valle Mexicano." Acta Anthropologica, Época 2, Vol. 1, Nro. 2. México: Escuela Nacional de Antropolgía e Historia, 1957 [1941].

MOTT, Luiz. A feira do anjo da guarda: estudos de uma Instituição Econômica num município Sergipano de São Francisco. Tese de doutorado em Antropologia, UNICAMP, Campinas, 1975.

Marchés ruraux au Nordeste du Brésil. In: Mainzer Geographische Studien, Mainz, 1976, p.11-16.

MAUSS, M. "Ensaio sobre a dádiva”. In: Sociologia e antropologia ([1950] 2003). São Paulo: Ed. Cosac Naify.

MINTZ, Sydney W. "Standards of Value and Units of Measure in the Fond-des-Negres Market Place, Haiti”. In: The Journal of the Royal Anthropological Institute of Great Britain 
and Ireland, Vol. 91, No. 1 (Jan. - Jun., 1961), pp. 23-38. Stable URL: http://www.jstor.org/stable/284446. (Acesso: 01/02/2012)

. "Pratik: Haitian personal economic relationship". In: POTTER, J., DIAZ, M., FOSTER, G. (ed.). Peasant Society: a reader. Berkeley, University of California; Boston, Little Brown and Co. 1987.

"Men, women and frade". In: Comparative studies in society and history. 13, 247-269, 1971.

"La utilization del capital por las vendedoras de mercado en Haiti". América indígena. 2, jul-set. México, Instituto Indigenista Interamericano, 1982.

RABOSSI, Fernando. Nas ruas da Cidade del Este: vidas e vendas num mercado de fronteira. Tese de doutorado em Antropologia Social, Museu Nacional, Universidade Federal do Rio de Janeiro, 2004.

SIGAUD, Lygia. “As Vendas das Pontas de Rua”. In: Anuário Antropológico, 1983, pp. 23 42.

SILVA, Lucas Carvalho e. Caracterização do setor atacadista de flores e plantas ornamentais no Brasil. Dissertação de mestrado em Agronomia/Fitotecnia, Universidade Federal de Lavras, 2012.

STOLLER, Paul. Money Has No Smell: Ethnography of West African Traders in New York City. Chicago: The University of Chicago Press, 2002.

VEDANA, Viviane. No Mercado tem tudo que a boca come. Tese de doutorado em Antropologia, Universidade Federal do Rio Grande do Sul, Porto Alegre, 2008.

WEBER, Max. "A dominação não-legítima (Tipologia das cidades)". In: Economia $e$ sociedade. Vol. 2. Brasília: UnB, 1979.

ZUKIN, Sharon. Paisagens urbanas pós-modernas: mapeando cultura e poder. In: (Arantes, Antonio A. org.) O espaço da diferença. Campinas, Papirus, 2000a.

Paisagens do século XXI: notas sobre a mudança social e o espaço urbano. In: Arantes, Antonio A. (org.) O espaço da diferença. Campinas, Papirus, 2000b.

. Loft living: cultural and capital in urban change. New Brunswick, Rutgers University Press, 1989.

"Consuming authenticity. From outposts of difference to means of exclusion". In:

Cultural Studies Vol. 22, No. 5 September 2008.

Recebido em: 15/09/2014

Aprovado em: 27/11/2014 